Peter Jurgec

Inštitut za slovenski jezik Frana Ramovša ZRC SAZU, Ljubljana

\title{
Začetne opombe k laringalizaciji v slovenščini
}

\begin{abstract}
Članek odpira nekaj možnosti za raziskovanje nemodalne fonacije v slovenščini na primeru laringalizacije oz. hripavega glasu. Predstavljene so pomembnejše splošne akustične in artikulacijske ugotovitve ter ekperimentalne analize posameznih jezikov. Sledi analiza laringalizacije na primeru standardne in narečne (ziljske) slovenščine. Avtor poskuša ugotoviti nekatere fonološke in fonetične prozodične vplive na pogostnost in vrsto laringalizacije $\mathrm{v}$ slovenščini. Upoštevana je tudi pragmatična, parajezikovna, sociolingvistična in zunajjezikovna raba laringalizacije.

The article opens up new possibilities for research into non-modal phonation in Slovene with regard to the case of laryngealization or creaky voice. The most important acoustic and articulatory findings and experimental analyses of individual languages are presented. Following this an analysis of laryngealization in case studies of standard and dialectal (Zilja dialect) Slovene is given. The author attempts to elucidate some of the phonological and phonetic prosodic influences on the frequency and type of laryngealization in Slovene. In addition, the author considers pragmatic, paralinguistic, sociolinguistic, and extralinguistic uses of laryngealization.
\end{abstract}

\section{Uvod*}

Problematika nemodalne fonacije ${ }^{1}$ je $\mathrm{v}$ fonetiki jasno prisotna že več kot pol stoletja: sem spadajo pregledna artikulacijsko- in akustičnofonetična dela, klasične eksperimentalnofonetične študije, raziskave govorne produkcije in njenih modelov, fonetično primerjalne monografije, študije posameznih jezikov in njihovih značilnosti v fonetičnem smislu, kakor tudi foniatrične in logopedske raziskave. Pregled tovrstnih raziskav sicer pokaže sprotno poglabljanje ugotovitev, kakšnih splošno veljavnih oz. prevladujočih rešitev pa še ni: modeli oz. taksonomija fonacije so precej neenotni, deloma si celo nasprotujejo (prim. dalje to besedilo). - Namen tega besedila seveda ni poseči v splošnofonetične razprave o fonaciji, temveč opozoriti na nekaj začetnih opazovanj o eni vrsti nemodalne fonacije, tj. hripavem glasu, v slovenščini - to kaže v nadaljnjih raziskavah nadgraditi. Pri tem se seveda ni mogoče izogniti razpravljanju o splošnih fonetičnih zadevah, vendar bom ostal pri temeljnem pregledu in čim bolj natančni opredelitvi te vrste fonacije, ki jo bom obravnaval na primeru slovenščine.

\section{Fonacija}

Ladefoged (1971: 7 in ss., 1973) navaja skupno devet možnosti fonacije, ki jih tu opredeljuje skoraj izključno artikulacijsko, tj. kot načine vibriranja glasilk. Te naj bi čim

* Besedilo je bilo pripravljeno z vnašalnim sistemom ZRCola, ki ga je na Znanstvenoraziskovalnem centru SAZU v Ljubljani (http://www.zrc-sazu.si) razvil Peter Weiss.

${ }^{1}$ Namesto izraza fonacija oz. pomensko prekrivno se v splošni in nekoliko starejši fonetični literaturi (tudi slovenski) pojavlja register, pri katerem gre poleg fonacije še za več drugih dejavnikov. Zato je za sodobno fonetično rabo manj primeren (gl. Laver 1980: 93-94 in tam dalje). 
bolje zajele kontinuum med dvema skrajnostma: popolnoma zaprtimi oz. odprtimi glasilkami. (Vrednosti lastnosti, ki se nanaša na položaj glasilk 〈glottal stricture〉, ${ }^{2}$ po Ladefogedu so v prikazu 1.) ${ }^{3}$ Vendar avtor sam doda, da so fonacijske možnosti v jezikih sveta (fonetično ali fonološko) omejene, tako da npr. razlikovanje med hripom in hripavim glasom za jezikoslovne potrebe ni potrebno (Ladefoged 1971: 15). V jezikoslovni fonetični literaturi kasnejšega datuma (npr. Johnson 1997: 127-130, Hayward 2000: 222 in s. s.) se zato uveljavlja predvsem razlikovanje med zamolklim glasom, modalno fonacijo in hripavim glasom - kot skrajni možnosti pa sta nezvenečnost na eni in glotalni zapornik 〈grlni zapornik $\rangle^{4}$ na drugi strani (poudarjeno v prikazu 1) - (gl. Ladefoged 1993: 139-141, Gordon in Ladfoged 2001), čeprav enotnega pojmovanja še vedno ni (prim. Titze in Talkin 1979, Klatt in Klatt 1990, Švec idr. 1996, Hanson 1997, Blomgren idr. 1998, Hanson in Chuang 1999, Švec idr. 2000, Berry 2001, Gerratt in Kreiman 2001, Hanson idr. 2001). Ladefoged in Maddieson (1996: 48) v svojem preglednem delu o fonetičnih značilnostih jezikov sveta uporabljata še vmesni oznaki slack in stiff voice (namesto lax in tense voice $\mathrm{v}$ tem zaporedju).

Prikaz 1: Vrste fonacije v jezikih sveta po Ladefogedu (1971: 17-18). Za komentar gl. besedilo.

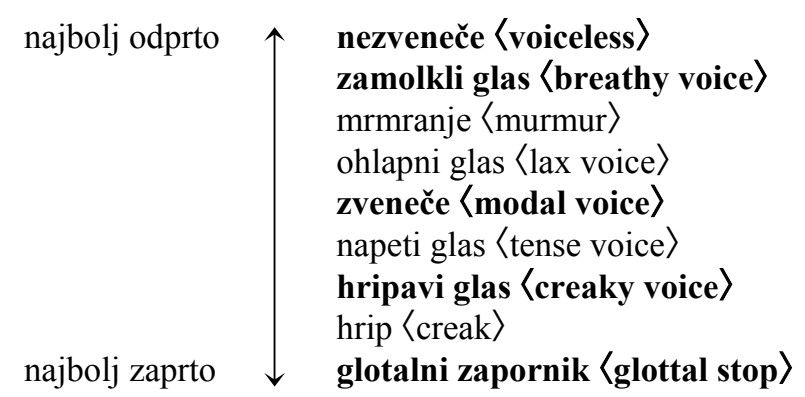

Precej drugačno tipologijo fonacije zagovarja Laver: poleg enostavnih vrst fonacije - modalne, falzeta, šepeta in hripa - navaja še 17 sestavljenih - med drugim hripavi in zamolkli glas, pa tudi šepetani glas〈whispery voice〉, rezki hripavi falzet〈harsh creaky falsetto〉, rezki šepetani hripavi falzet 〈harsh whispery creaky falsetto〉 ipd. (Laver 1980). Na drugem mestu avtor navaja skupno 16 vrst fonacije, ki so kombinatorno dokaj omejene (1994: 199). Po Hollienu (1974) naj bi bile vrste fonacije (oz. registri) trije, falzet, modalni oz. prsni register in hrip (oz. vocal fry, glottal fry oz.

\footnotetext{
${ }^{2}$ Izrazje, ki ga želim uveljaviti, je opremljeno z drugimi (tujimi oz. angleškimi - pri čemer uporabljam ameriški standard, razen pri navajanju -, če se pojavljajo kot prevedek na novo, ali domačimi, če je predlagana drugačna rešitev) ustreznicami, ki so zapisane v lomljenem oklepaju. Kjer je le mogoče, uporabljam že uveljavljen slovenski izraz, četudi je manj ustrezen.

${ }^{3}$ Čeprav je tipologija Ladefogedova, je avtor poimenovanja glavnih vrst fonacije Catford (1964, 1977).

${ }^{4}$ Poimenovanje grlni zapornik se uveljavlja v slovenski fonetični literaturi zadnjega časa, čeprav je termin zavajajoč: mesto zapore je namreč glotis. Zato tu za [?] uporabljam izraza glotalni zapornik oz. glotalna zapora.
} 
pulse register phonation, ${ }^{5}$ dalje gl. razdelek 3). Pri Catfordu (1977: 93 in s. s., posebej še 106) je štirim osnovnim fonacijskim tipom, tj. nezvenečemu, zvenečemu, šepetu in hripu, dodanih še devet sestavljenih, ki so vsi dvojno odvisni od značilnosti glasilk (odprtostna stopnja in mesto). - V nadaljevanju se bom omejil na razpravljanje o razlikah med zamolklo in hripavo fonacijo v razmerju do modalne.

Večino jezikovno (fonetično in fonološko) relevantnih nasprotij v naravnih človeških jezikih je mogoče opredeliti zgolj s [ \pm zveneče $]$ in $[ \pm$ pridihnjeno] $\langle[ \pm$ aspiracija $]\rangle$, medtem ko so drugi fonacijski kontrasti redkejši. Samo majhno število jezikov nemodalne vrste fonacije uporablja fonološko razlikovalno. Gordon in Ladefoged (2001) navajata 45 jezikov, ki imajo vsaj eno vrsto nemodalne fonacije in so bile zanje narejene akustične študije (v glavnem gre za jezike različnih jezikovnih družin Severne in Južne Amerike, Afrike in Azije, tudi trije indoevropski), nekaj celo več kot eno. Nemodalno fonacijo diahroni jezikoslovci povezujejo tudi s tonogenezo; Hombert idr. (1979) tako ugotavljajo precejšnjo verjetnost, da toni nastajajo iz prekategorizacije segmentnih elementov, tj. predsamoglasniških neglotalnih zapornikov ali posamoglasniškega glotalnega, v nadsegmentne, verjetno prek faze laringalizacije (prim. tudi Greenberg 2004). Purcell idr. (1978) eksperimentalnofonetično dokazujejo zvezo med prvotnimi zamolklimi soglasniki v hindiju in kasnejšim tonom v pandžabščini.

Zamolkli glas ${ }^{6}$ opredeljujejo artikulacijsko razprti piramidasti hrustanci in manjša stopnja longitudinalne (Ladefoged 1971: 12) in medialne mišične napetosti glasilk nizka je stopnja prizetezanja (addukcije) -, to pa je povezano z večjim odprtostnim koeficientom〈open quotient〉, oz. relativnim časom odprtosti glasilk, večji je tudi hitrostni koeficient 〈speed quotient〉, kar pomeni nekoliko hitrejši zračni pretok. Slušno so nekoliko bolj šumni. Akustično je značilen tudi drugačen spektralni nagib 〈spectral tilt〉, Huffman (1987: 502) tako za zamolkli nizki ton v hmonščini 〈Hmong, BLU〉 ${ }^{7}$ ugotavlja precej večjo razliko med osnovno frekvenco $\mathrm{F}_{0}$ in drugo harmonsko frekvenco $\mathrm{H}_{2}$ (to velja tudi za zamolkle samoglasnike jalapske mazateščine 〈Jalapa Mazatec, MAJ〉, jezika !xoo 〈!Xóõ, NMN〉) (Ladefoged 1983, Ladefoged idr. 1988) in gudžaratščine 〈Gujarati, GJR〉. V jeziku cónga 〈Tsonga, TSO〉 je razlike med zamolklimi in modalnimi nosniki najbolj jasne $\mathrm{v}$ spekralnem nagibu, variantnost med posameznimi govorci je tu najmanj relevantna (Traill in Jackson 1988). Zelo znan primer zamolklih zapornikov je hindi (prim. Banguerel in Bhatia 1980, Dixit 1989) - ti so znani tudi kot zveneči pridihnjeni. Klatt in Klatt (1990) navajata, da je za ženske govorke ameriške angleščine značilna v povprečju večja stopnja zamolklosti, čeprav so individualne razlike precejšnje (prim. tudi Klatt in Klatt 1990, Hanson 1997, Hanson in Chuang 1999). $\mathrm{Z}$ zamolklim glasom je v slovenščini na primer ponavadi izgovorjen glas, ki ga v medmetu aha zapisujemo s srednjo črko.

\footnotetext{
${ }^{5}$ Izrazov te vrste načeloma ne prevajam, saj njihova raba v slovenščini iz na tem mestu navedenih razlogov ni priporočljiva oz. smiselna, razen zgolj zaradi terminologije.

${ }^{6}$ Angleška izraza breathy voice in murmur se danes prevladujoče rabita sinonimno, pri čemer je slednji po rabi splošnejši, torej manj strokoven.

${ }^{7}$ Po v virih prevladujočem poimenovanju poslovenjeni manj znani jeziki so opremljeni z izvirnim (angleškim) poimenovanjem, in ko je mogoče iz virov nedvoumno določiti jezik, še s kodo SIL (Ethnologue 2005).
} 
Hripavi glas $^{8}$ nasprotno označujejo ravno nasprotne artikulacijske značilnosti: piramidasti hrustanci so stisnjeni skupaj, tako da lahko vibrira samo sprednji del glasilk (Ladefoged 1971: 14): značilno je tesno prizetezanje, glasilke so zožene, kar povzroča precejšnjo medialno tenzijo, medtem ko je longitudinalna sorazmerno nizka. Artikulacijsko je hripavi glas torej nasproten zamolklemu glede na $\mathrm{v}$ fonetiki privzetega modalnega: nižji sta odprtostni in hitrostni koeficient, posledično je nižji tudi subglotalni tlak (prim. Murry 1971, Laver 1980: 109 in s. s., Ladefoged idr. 1988, Ní Chasaide in Gobl 1997: 444-451, Berry 2001, Hanson idr. 2001, Ladefoged 2003: 169-181; za drugačne rezultate o zadnjem gl. McGlone in Shipp 1971). Avditivni vtis Catford (1964: 32) opisuje kot »rapid series of taps, like a stick being run along a railing «.

Prikaz 2: FFT-spekter z oknom $50 \mathrm{~ms}$ za ['á:i] (zgoraj) in ['á:] v besedi pardon, kakor jo je izgovorila govorka 03zt (prim. prikaz 11). Za komentar gl. besedilo.
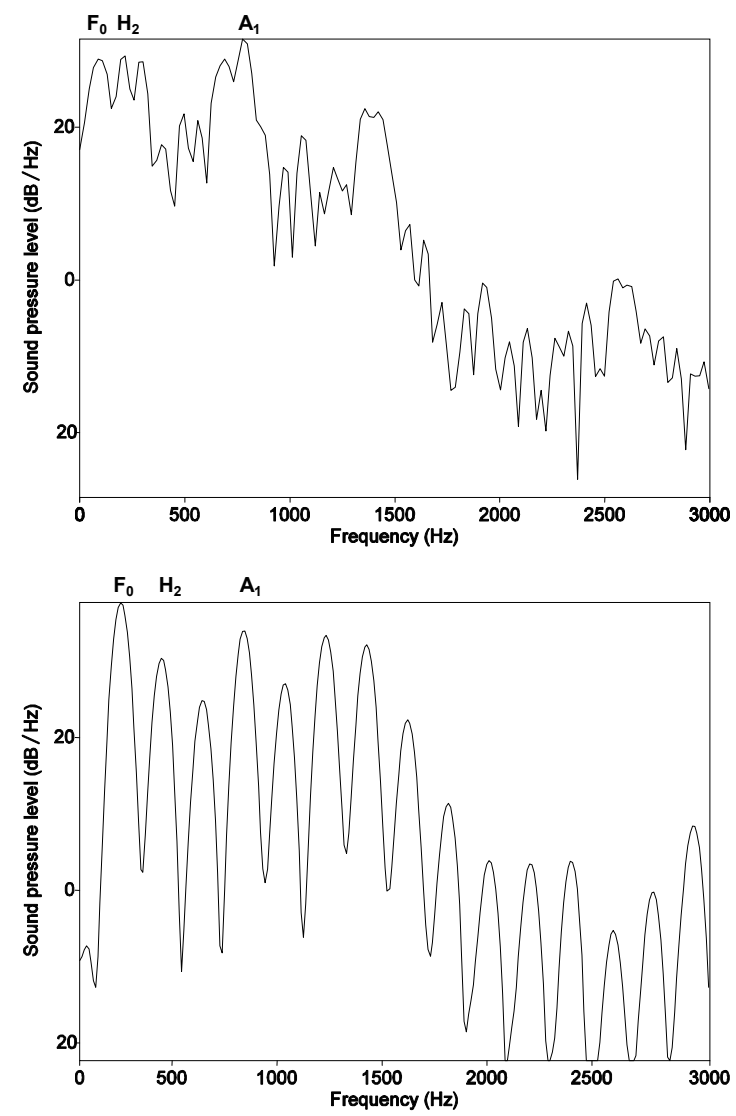

${ }^{8}$ Prevedena besedna zveza hripavi glas je lahko precej zavajajoča: te vrste fonacije ne gre povezovati s hripavostjo kot bolezenskim stanjem. Izraz se nanaša samo na slušni vtis, pri hripavosti kot vrsti laringalne patologije pa gre za motnje zaradi bolezenskih sprememb glasilk (npr. operativni posegi, maligne ipd. tvorbe), ki akustično in artikulacijsko ne odgovarjajo tu opisanim značilnostim. 
Akustično ga lahko opišemo $\mathrm{z}$ več spremenljivkami. Literatura kot glavno značilnost navaja nizko osnovno frekvenco (celo $50 \mathrm{~Hz}$, tako da so posamezni glotalni pulzi slušno zaznavni; prim. še razdelek 3 za vocal fry), glotalni pulzi so izrazito neenakomerni, kar je mogoče podati tudi količinsko v obliki variance osnovne frekvence〈jitter〉. Značilna je tudi relativno nižja amplituda najnižjih harmonskih frekvenc (tako v primerjavi $\mathrm{z}$ modalno kot $\mathrm{z}$ zamolklo fonacijo). Pri spektralnem nagibu raziskave tipično primerjajo osnovno frekvenco in prvo višjo harmonsko frekvenco $\left(\mathrm{H}_{2}\right)$, kot dodatno merilo se pojavlja še prvemu formantu $\left(\mathrm{F}_{1}\right)$ najbližja harmonska frekvenca, kar je največkrat harmonska frekvenca za najvišjo amplitudo $\left(\mathrm{A}_{1}\right)$, redkeje tudi tretjemu formantu najbližja $\mathrm{A}_{3}$ - prim. Ladefoged idr. 1988: 298-309, Klatt in Klatt 1990: zlasti 822, 828-830, Hanson 1997: 468 in s. s., Ní Chasaide in Gobl 1997: 446, 449-451, Hanson in Chuang 1999: 1065 in s. s., Hanson idr. 2001: 459460, ter Gordon in Ladefoged 2001: 386-391, 397-399 in tam dalje za raziskave manj razširjenih jezikov). To je jasno razvidno tudi pri tipičnih primerih hripavega glasu v slovenščini. Prikaz 2 ponazarja razliko v FFT-spektru za hripavi ['a:] in modalni ['a:] za dve ločeni pojavitvi besede pardon. Amplituda osnovne frekvence hripavega je tipično nekoliko nižja kot pri modalnem (za zamolklega je razmerje ravno obratno), je pa relativno višja za drugo harmonsko frekvenco in prvi formant. (Očitna je tudi neenakomernost $\mathrm{F}_{0}$ pri hripavem glasu).

Akustična lastnost hripavega glasu je tudi nekoliko nižja intenziteta v primerjavi $\mathrm{z}$ modalno fonacijo (to velja tudi za zamolkli glas), kar je jasno vidno na spektrogramih in valovnih oblikah v prikazih 5 in dalje. Fonetične raziskave posameznih jezikov, $v$ katerih je hripavi glas (tudi) fonološki, so pokazale, da je povezan $\mathrm{z}$ višjim $\mathrm{F}_{1}$ in ponekod tudi z daljšim trajanjem (prim. Gordon in Ladefoged 2001: 400 za obravnave posameznih jezikov, kjer je hripavi glas fonološki). - O pojavljanju hripavega glasu v jezikih sveta bom razpravljal v razdelku 8.

\section{Laringalizacija}

Izraz laringalizacija 〈laryngealizaton〉 (prim. že Lehiste 1970: 60) je pomensko nekoliko širši od hripavega glasu, čeprav ga Ladefoged (npr. Ladefoged 1971, 1983, 1988, 1993, Ladefoged idr. 1988, Ladefoged in Maddieson 1996, Gordon in Ladefoged 2001) večinoma uporablja kar sopomensko. ${ }^{9}$ Anglo-ameriška fonetična literatura druge polovice 20. stoletja namreč poleg hripavega glasu pozna še več sorodnih (pomensko prekrivnih oz. celo sopomenskih, prim Trask 1996) izrazov, za katere ni vedno popolnoma jasno, kaj natančno pomenijo. Načeloma velja, da se vsaj v literaturi novejšega datuma pojavljajo takrat, ko avtor želi poudariti katero izmed akustičnih, artikulacijskih oz. slušnih lastnosti, ki so najbolj tipična za posamezen termin.

Popolnoma sinonimno se med seboj uporabljajo izrazi vocal fry, glottal fry, pa tudi pulse (register) phonation, ki označujejo hripu podobno fonacijo (táko z značilnim dušenjem), katere glavne značilnosti so nepravilni glotalni intervali (sinkopični ritem $v$ Wendahl idr. 1963) in zelo nizka osnovna frekvenca (celo $20 \mathrm{~Hz}$ in manj), medtem ko se natančni artikulacijski opisi - tudi na podlagi laringoskopskih raziskav - precej razlikujejo. Tako Whitehead s sodelavci (1984) poroča celo o konsistentnih dvojnih in

\footnotetext{
${ }^{9}$ Vendar prim. Ladefoged 1988: 374, kjer mu izrazi creaky, laryngealized in stiff pomenijo različne stopnje (addukcije).
} 
trojnih glotalnih pulzih, ki jim v enem ciklu sledi dolga faza, ko so glasilke zaprte. Podatki v Hollien idr. 1977, Švec idr. 1996 in Švec idr. 2000 pa nasprotujejo opredeljevanju tega tipa fonacije kot hripavi glas, saj je sobglotalni pritisk drugačen; take diplofonične lastnosti imajo sicer drugi avtorji (npr. Klatt in Klatt 1990: 823) za značilnosti hripavega glasu (oz. hripa kot enostavne fonacijske možnosti po Laver 1980). Za podrobnejšo analizo gl. Blomgren idr. 1998. Prim. še zgodnejše raziskave Moore in von Leden 1958: 224 in s. s., Coleman 1963, Hollien idr. 1966, Hollien in Michel 1968, Michel in Hollien 1968, Hollien in Wendahl 1968, McGlone in Shipp 1971, Murry 1971, Allen in Hollien 1973.

Termin glotalizacija 〈glottalization〉 je še nekoliko širši, saj razen hripavega glasu na eni in glotalnega zapornika na drugi strani zajema še razne vmesne stopnje: Dilley idr. (1996: 428-430) navajajo še upad osnovne frekvence in amplitude vzglasnih samoglasnikov kot akustični ustreznik avditivni glotalizaciji. Glotalizacijo nekateri viri povezujejo tudi z implozivi in ejektivi; tako poimenovano laringalizacijo Laver (1994: 330 idr.) razume kot sekundarno artikulacijo, kakršna se kaže v nekaterih kanoničnih splošno fonetičnih primerih, npr. pri zveneči aspiraciji v hindiju (prim. Banguerel in Bhatia 1980, Dixit 1989) ali danskem stødu (gl. Fischer-Jørgensen 1989 in tam dalje). Ladefoged (1988: 375) zaradi pomenske nejasnosti ta termin odsvetuje. V fonološki rabi sta še izraza checked in pressed.

V nadaljevanju bom laringalizacijo uporabljal kot nekoliko splošnejši izraz od hripavega glasu, saj bom tako lahko opisal tudi pojave, ki zanj niso najbolj tipični; jedro obravnave v nadaljevanju je hripavi glas v slovenščini.

\section{Laringalizacija v slovenščini}

Vidiki nemodalne fonacije $\mathrm{v}$ jezikoslovnem kontekstu $\mathrm{v}$ zvezi s slovenščino še niso bili obravnavani, večinoma so se omejili na omembo avditivnih količin, kakršna sta ${ }^{\dagger}$ register (gl. opombo 1 tega besedila) ali ${ }^{\dagger}$ zastavek (oboje Omerza 1970: 21 in s. s.). Drugače je bilo kar nekaj fonetičnih obravnav že s konca 19. stoletja dobro znanega $» / \mathrm{q} / \ll\left(<\right.$ psl. $\left.{ }^{*} \mathrm{k}\right)$ v slovenskih koroških narečjih, tj. delu rožanskega in podjunskega narečja, kar povzema Neweklowsky (1970) in poleg fonoloških vidikov obravnava tudi fonetični vidik. Iz reproduciranih spektrogramov je lepo videti, da [?] pogosto prosto variira s hripavim glasom. Priestly (1976) se ukvarja posebej z vprašanjem variacije med [?] in laringalizacijo (oz. hripavim glasom). Podatki Neweklowskega, poznavanje splošne fonetike in sorodnih študij za druge jezike ter njegova analiza posnetkov iz Sel (zlasti odvisnost od trajanja), mu omogočajo trditev, da »the variation between glottal stop and laryngealization in the Sele Fara dialect depends on speech tempo, and also (directly or indirectly) on the rhythm of the sentence«, tako da je [2] bolj verjeten, če je tempo počasnejši (Priestly 1976: 272-273). Na drugem mestu (1980) ugotavlja štiri možnosti realizacije predloga $k$ (+ dajalnik): običajni prehod, pavzo, glotalni zapornik, laringalizacijo (tudi kot hripavi glas), kar naj bi bil bilo odvisno od sledečega segmenta: fonetična realizacija je verjetnejša, če sledi beseda na samoglasnik ali zvočnik (analizira skupaj 22 primerov, laringalizacija je prisotna $\mathrm{v} 8$, [?] pa $\mathrm{v} 4$; n. d., 29).

Glotalni zapornik se (lahko) pojavlja tudi $\mathrm{v}$ govorjeni standardni slovenščini (prim. omembo v Bezlaj 1960: 52), kar sem opazil, ko sem se ukvarjal s samoglasniškimi nizi: analiza okoli 300 minut oddaje Studio ob sédemnajstih je pokazala konsistentno pojavljanje [?] v vzglasju besed na samoglasnik pri posameznih govorcih, zelo 
pogostni so bili pri leksikalno zaznamovanih besedah, npr. krajšavah ali medmetih (Jurgec 2004a: 138-140, 2005b: 132-135). Hripavi glas se ponekod pojavlja variantno s [?] / V_V (prim. prikaza v 2005b: 218).

Nemodalna fonacija je zanimiva tudi s stališča diahronega jezikoslovja. Greenberg $^{10}$ (2004: 5-6), ki sicer izhaja iz Vaillant-Kortlandtove teorije o glotalnem zaporni$\mathrm{ku} \mathrm{v}$ balto-slovanski tonogenezi, to nadgradi $\mathrm{z}$ vprašanjem o fazi hripavega glasu $\mathrm{v}$ slovenščini med 9. in 12. stoletjem, ki bi lahko pojasnila sinhrono stanje v fonetični realizaciji tonov, zlasti seveda slovenskega rastočega akuta (v primerjavi npr. s kajkavskim).

\section{Metoda}

Jedro obravnave je laringalizacija v slovenščini, ki sem jo pilotsko raziskal za standardno slovenščino in ziljski govor v Kanalski dolini. Raziskava temelji na gradivu, ki ni bilo posebej zbrano $\mathrm{v}$ ta namen, ampak je bilo uporabljeno že za druge fonetične raziskave.

Gradivo standardne slovenščine (gradivo 1) so posnetki 275 izolirano izgovorjenih besed oz. besednih zvez. Večina, 241 (87,6 \%), je izbranih eno-, dvo- in trizložnic glede na vse $\mathrm{v}$ standardni slovenščini mogoče kombinacije nadsegmentnih lastnosti, tako da je bil izbran karseda enakovreden delež glede na vse spremenljivke, razen seveda če ni kakšnih fonoloških omejitev (dalje o tem gl. Jurgec 2004b: 13-14, 63-72). Temu je dodano še 34 besed s samoglasniškimi nizi in nosniki, različne glede na položaj v besedi, dolžino besed oz. segmentne kombinacije. ${ }^{11}$ Te besede je izgovorilo deset govorcev, ki so bili izbrani, kolikor je bilo mogoče, reprezentativno glede na starost, spol, geografsko pripadnost, razlikovalni leksikalni ton (tonemskost). ${ }^{12}$ Snemanje je bilo studijsko in ob standardnih pogojih (frekvenca vzorčenja 44,1 kHz, 16-bitna kvantizacija itd.), o tem prim. Jurgec 2004b: 18. Posnetke (v celoti 204 minute in 9 sekund) sem poslušal po trikrat in na podlagi slušne in spremljajoče digitalne spektrografske in oscilografske analize v programih Praat in Cool edit izločil enote, v katerih je bila laringalizacija tako slušno kot akustično nedvoumna. Dvomljive primere (gl. dalje) sem izločil iz nadaljnje obravnave.

Narečno gradivo (gradivo 2) predstavlja govor govorke iz Ovčje vasi (Kanalska dolina, ziljsko narečje). Analizirani govor je bil izločen iz daljšega prostega intervjuja, ki je bil posnet na terenu, pri informantki doma; posnetek na avdiokaseti je bil digitaliziran s frekvenco vzorčenja $22,05 \mathrm{kHz}$ in s 16-bitno kvantizacijo v enokanalnem načinu. (To je posnetek zelo slabe kvalitete.) Skupna dolžina je 28 minut in 44 sekund (dalje gl. Jurgec 2005a). Dodatno gradivo so bili posnetki iste govorke v obliki kratkih

\footnotetext{
${ }^{10}$ Uredniku se na tem mestu zahvaljujem, ker me je spodbudil k obravnavi hripavega glasu v slovenščini.

${ }^{11}$ Celoten spisek besed je na voljo pri avtorju.

12 Oznake govorcev so sestavljene iz dvomestne zaporedne številke govorca (01), znaka za spol $(\mathrm{m}, \mathrm{z})$ in tonemskost oz. netonemskost $(\mathrm{t}, \mathrm{n})$. Geografsko poreklo govorcev: 01zn - Otovci, 02zn Spodnja Kungota, 03zt, 04zt, 05zt - Ljubljana, 06mn - Blanca, 07mn, 08mt - Ljubljana, 09mt - Vnanje Gorice, $10 \mathrm{mn}$ - Nova Gorica.
} 
izsečkov, ki jih je posnela Karmen Kenda-Jež, ${ }^{13}$ in so boljše kvalitete, zato so tu reproducirani. Smiselno je bilo upoštevano tudi še pribl. 30 minut govora moškega govorca iz Ukev. - Laringalizacija je bila tako kot za standardni jezik določena slušno, preverjena pa še na podlagi digitalne akustične analize.

\section{Rezultati: standardna slovenščina}

Do hripavega glasu je prišlo v 585 enotah gradiva 1 (ali 11,6 \%), pri čemer je treba upoštevati, da gre ponavadi le za en glas oz. njegov del, nekaj je pojavitev dveh z modalno fonacijo ločenih delov. Kot so ugotovile že druge raziskave (npr. Umeda 1978, Streeter 1978 Klatt in Klatt 1990, Holmberg idr. 1996, Dilley idr. 1996, Hanson 1997 in Redi in Shattuck-Hufnagel 2001), so individualne razlike v deležu hripavega glasu (ali glotalizacije) precejšnje: v našem primeru ima najmanj pojavitev s hripavim glasom govorec $09 \mathrm{mt}$, tj. 9 oz. 1,8 \% (je pa zamolkost splošna značilnost njegovega glasu), medtem ko ima govorka 02zn kar dobrih 13-krat več pojavitev, tj. 118 oz. 23,4 \% (podatki so v prikazu 3). Porazdelitev pojavitev po govorcih na intervalu $0-125$ je v prikazu 4.

Prikaz 3: Delež laringaliziranih (izoliranih intonacijskih) enot v gradivu 1 po govorcih.

\begin{tabular}{cccccccccccc}
\hline \hline govorec & 01zn & 02zn & 03zt & 04zt & 05zt & $06 \mathrm{mn}$ & $07 \mathrm{mn}$ & $08 \mathrm{mt}$ & $09 \mathrm{mt}$ & $10 \mathrm{mn}$ & povpr. \\
\hline št. & 31 & 118 & 69 & 100 & 24 & 18 & 47 & 66 & 9 & 103 & 58,5 \\
v \% & 6,1 & 23,4 & 13,7 & 19,8 & 4,8 & 3,6 & 9,3 & 13,1 & 1,8 & 20,4 & 11,6 \\
\hline \hline
\end{tabular}

Čeprav je skupno število laringaliziranih enot nekoliko večje za ženske govorke in tonemske govorce, pa razlike po spolu $(p=0,453)$ ali glede na razlikovalni leksikalni ton $(\mathrm{p}=0,714)$ niso statistično značilne.

Prikaz 4: Porazdelitev števila laringaliziranih enot po govorcih.

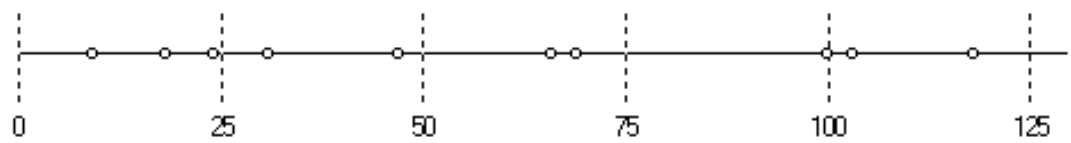

Laringalizacija v izoliranih besedah gradiva 1 je tipološko več vrst, pri čemer dejstvo, da gre za izolirane leksikalne enote, nekoliko omeji natančno tipologiziranje. Zato bom laringalizacijo v nadaljevanju ločil glede na mesto pojavljanja v enoti oz. glede na posamezen glas. Tako se laringalizacija lahko pojavlja (1) na začetku intonacijske enote, pri čemer je laringaliziran njen prvi del; ta tip laringalizacije je tudi prehodnega tipa, tj. med dvema glasovoma, zlasti v tipu V $]_{b}[\mathrm{~V}$. Precej pogosto je laringaliziran (2) nevzglasni del enote, kjer je laringalizacija prisotna največkrat po celotnem segmentu (tj. ne samo v njegovem začetnem delu) ali še nekoliko dlje; tovrstna laringalizacija je zelo pogostna $\mathrm{v}$ izglasju. Posamezne intonacijske enote so (3) v celoti laringalizirane.

${ }^{13}$ Zahvaljujem se Karmen Kenda-Jež za preverjanje mojih zapisov (pri tonemih in sredinskih samoglasnikih) in del gradiva. - Vse morebitne napake so moje. 
Razpravljanje o splošnih tipoloških značilnostih laringalizacije s fonološkega stališča se nadaljuje v razdelku 8 .

\subsection{Laringalizacija tipa 1}

Vzglasni tip laringalizacije je precej pogosten in je značilno alofonski. Dosedanjim ugotovitvam o variantnosti [?] v besedah s samoglasniškim vzglasjem v slovenščini (Jurgec 2004a) se pridružuje še ugotovitev, da se alofonsko v tovrstnih besedah pojavlja tudi laringalizacija. Skupen delež enot na samoglasnik v gradivu 1, ki imajo bodisi eno samo glotalno zaporo kot kanonični primer [?] bodisi jih je več, kar štejemo za laringalizacijo, je vsaj 30,2 \%, vendar se delež izrazito razlikuje po govorcih (od 7 do $71 \%$, pri čemer imata zanimivo najnižji delež prav profesionalni govorec $08 \mathrm{mt}$ in jezikoslovec $09 \mathrm{mt}){ }^{14}$ laringaliziranih (tudi nesamoglasniških) vzglasij pa je 108 . To je precej podoben delež, kot ga je na manjšem narečnem gradivu za predlog $k$ ugotovil Priestly (1980: 29), in je podoben stanju v nemščini (Kohler 1994) - prim. dalje razdelek 8. - Primer laringalizacije te vrste je v prikazu 5. Kar nekaj pojavitev laringalizacije in glotalnega zapornika je pri besedah na vzglasne zvočnike [1], [m], [j], [n] (nav. po padajoči pogostnosti).

Prikaz 5: Laringalizacija v besedi avtobus /'à:vtobus/, kakor jo je izgovorila govorka 03zt (prikazan je samo začetek besede do zapore [b]). Na spektrogramu in oscilogramu so lepo vidne posamezne (neenakomerne) striacije oz. glotalni pulzi v prvi polovici [a]. Valovna oblika 〈oscilogram〉 ima jasno pojemajočo amplitudo v primerjavi z zvenečo modalno fonacijo (prim. obe polovici /a/). ${ }^{15}$

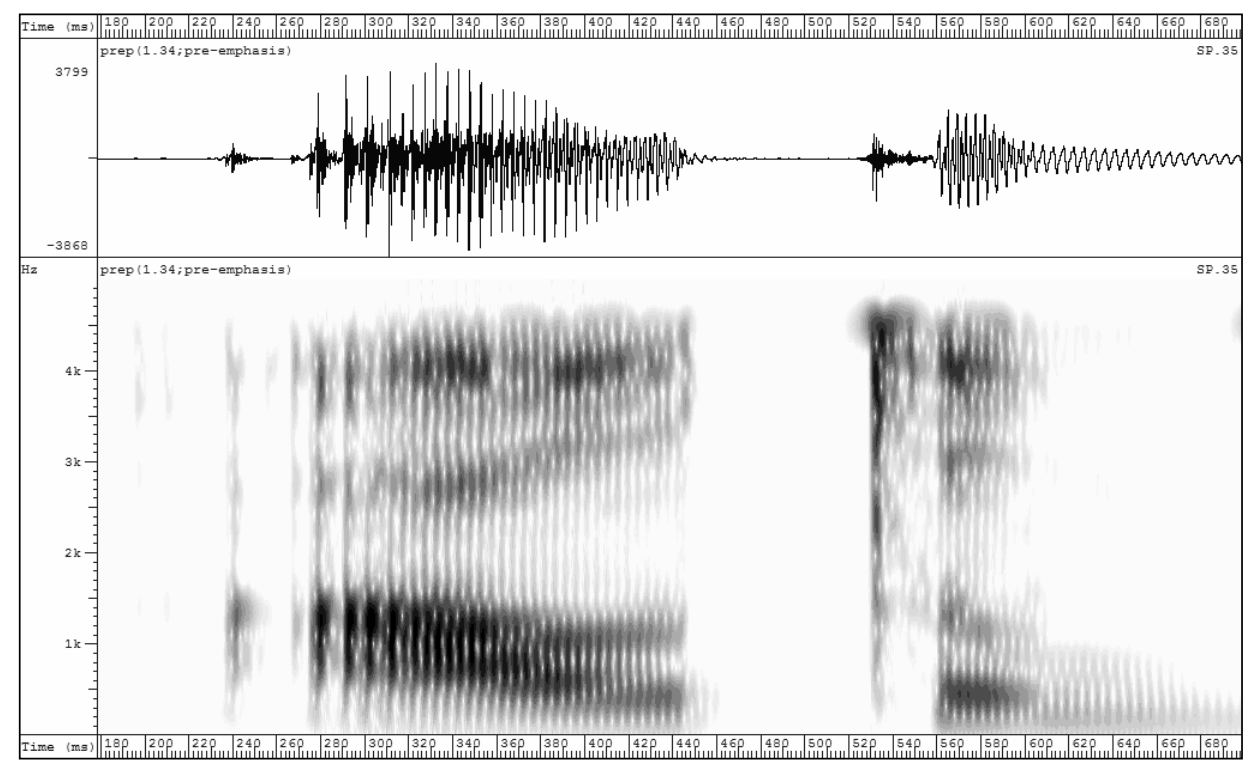

\footnotetext{
${ }^{14}$ Pri oceni je treba upoštevati tudi dejstvo, da nabor besed z vzglasnimi samoglasniki ni uravnotežen, kar se tiče fonoloških in fonetičnih spremenljivk.
} 
Prikaza 6a in 6b: Krajšava $E U$, realizirana kot samoglasniški niz s tranzientskim delom (6a, zgoraj) ali z laringalizacijo (6b, spodaj).
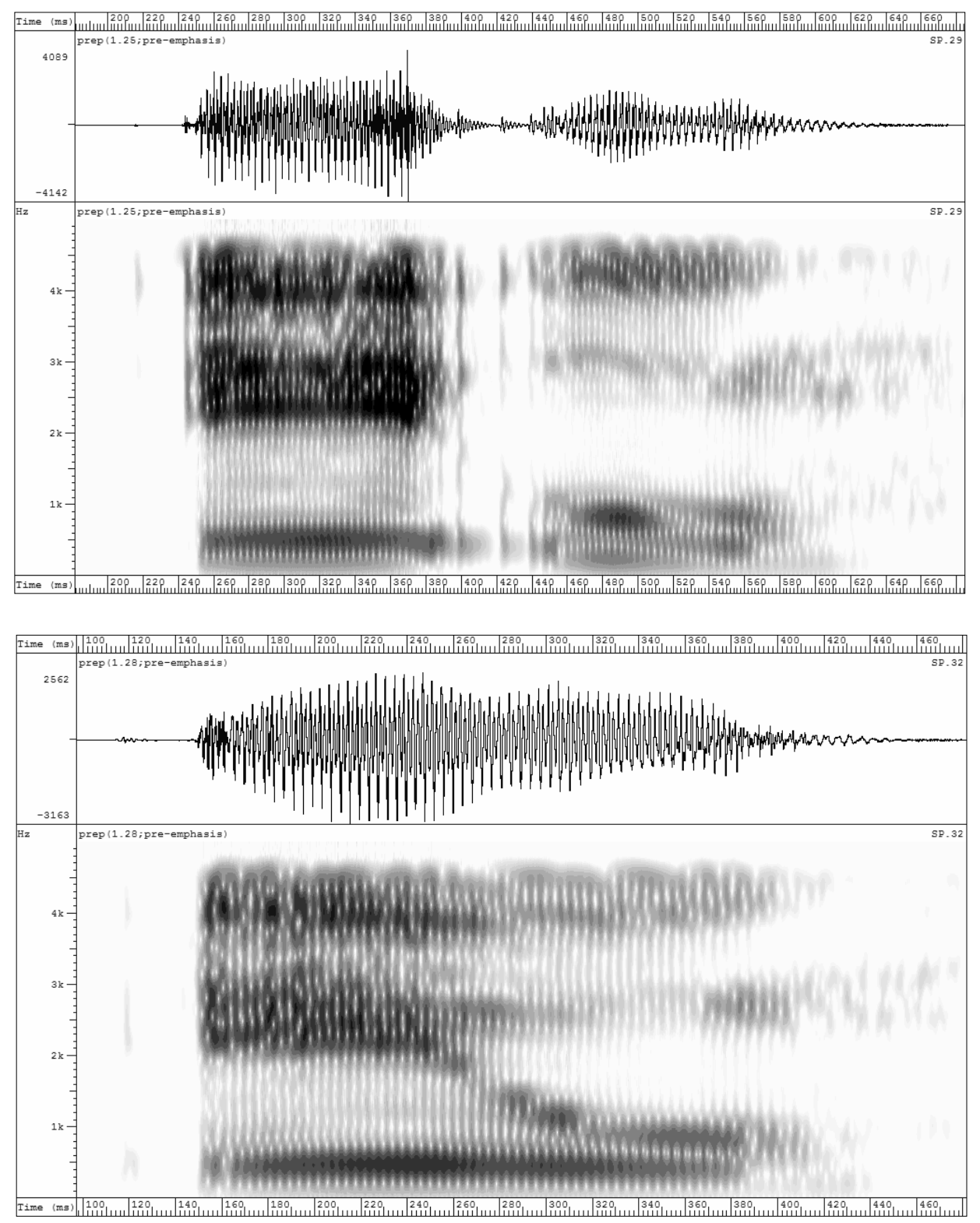

${ }^{15}$ Za grafične predstavitve (oscilograme, spektrograme itd.) je uporabljen program Speech filing system. Posnetki so ponovno vzročeni s frekvenco $10 \mathrm{kHz}$, višje frekvence okrepljene 〈pre-emphasis〉. 
Ker je gradivo 1 sestavljeno tako, da nadleksikalnih elementov ne moremo opazovati (poenoteni so na intonacijsko enoto \#[ ]\#, ki se realizira bodisi kot končna rastoča, nevtralna /tudi leksikalno razlikovalna glede na ton/ in padajoča; rastoča intonacija je tudi sicer v takih kontekstih nekoliko bolj značilna za ženske govorke), o vzrokih za variantnost glotalni zapornik : laringalizacija : brez glede na položaj v intonacijski enoti ne morem pisati. Opazno več je je le v krajšavah, kjer je pogosten še drugi podtip laringalizacije, in sicer na morfemski meji tipa $\mathrm{V}]_{\mathrm{m}}[\mathrm{V}$.

Največkrat je laringalizacija na morfemski meji $\mathrm{V}]_{\mathrm{m}}[\mathrm{V}$, prisotna $\mathrm{v}$ krajšavah (primera $O Z N$ /oze' $\varepsilon$ n/, $E U$ /e'ù: / v gradivu 1), in sicer v večini primerov, medtem ko je na morfemski meji pri zloženkah z medponskim obrazilom redkejša (severnoevropski /,sé:vernoev'rò:pski/) - v gradivu je samo ena taka pojavitev.

$\mathrm{V}$ omenjenih primerih laringalizacija zamenja modalni tranzientni del samoglasniškega niza (prim. Jurgec 2005b: 113-115), laringalizacija je pogostejša v medmorfemskih samoglasniških nizih, v znotrajmorfemskih (npr. oaza /o'à:za/) je redkejša. Samoglasniški niz v tipu severnoevropski $\cong$ makroekonomski se lahko realizira tudi kot pavza (ni potrditev v gradivu 1, vendar prim. Jurgec 2004a: 140, 2005b: 135, 219). - V prikazih $6 \mathrm{a}$ in $6 \mathrm{~b}$ sta realizaciji krajšave $E U$ glede na prisotnost oz. odsotnost laringalizacije.

V gradivu 1 sem našel tudi pojavitve, v katerih je hripavi glas fonetični ustreznik /j/, npr.

(1) kupčija /kup'tìja/ $\rightarrow\left[\mathrm{k}^{\mathrm{h}} \mathrm{up}^{\prime} \mathrm{t}\right.$ ìiria $]$

inflacija /iN'flá:tsija/ $\rightarrow$ [ĩm'flá:tsiia]

ki seveda še spadajo v ta tip, čeprav je fonološki in leksikalni kontekst drugačen.

\subsection{Laringalizacija tipa 2}

Drugače kot pri vzglasju se realizira laringalizacija znotraj besede, največkrat pa $\mathrm{v}$ izglasju. Če pri laringalizaciji tipa 1 velja variantnost z glotalnim zapornikom oz. pavzo, je pri tem tipu ni.

Fonetično gre največkrat za hripavi glas, ki se večinoma pojavlja v celotnem samoglasniku, v izglasju pa $\mathrm{v}$ njegovem delu (tudi prvem), nekaj je tudi takih primerov za [u], [1] in [m], ki so iz nadaljnje (statistične) obravnave na tem mestu izločeni. Pri dveh govorkah (01zn, 04zt) je bilo opaziti precej konsistentno diplofonijo, ki je bila največkrat večja $v$ prvem delu izglasnih samoglasnikov; kaže se kot izrazito neenakomerni, vendar ponavljajoči se vzorec zaporednih period; kar je opaženo tudi v literaturi (Klatt in Klatt 1990, Švec idr. 1996, Švec idr. 1999, Redi in Shattuck-Hufnagel 2001, Gerratt in Kreiman 2001, Hanson idr. 2001). Vendar sem večino takih primerov izločil kot dvomljive. Nekaj je tudi primerov (največ pri govorcih $8 \mathrm{mt}$ in $10 \mathrm{mn}$ ) subharmonskega nihanja, ki je soroden diplofoničnemu, le da je enakomernejši. Ker ta tip ni nujno laringalizacija (prim. Švec idr. 1996 in Švec idr. 2000), čeprav so jo kot tako klasificirale nekatere starejše študije (npr. še Klatt in Klatt 1990), sem jih pretežno izločil kot dvomljive. Pri moških govorcih z zelo nizko osnovno frekvenco (tipično govorec 08mt) je opaziti nekoliko več hripavega glasu pri samoglasnikih, ki imajo nizek ali nizek padajoč tonski potek (na koncu intonacijske enote ali tudi pri cirkumfleksih). Taki primeri govorca 09mt (bodisi akutirani bodisi cirkumflektirani) so bili izločeni kot dvomljivi (zato ima ta govorec tudi najnižji delež laringaliziranih enot, prim. prikaz 3). - Nekaj primerov laringalizacije je v prikazih $7 \mathrm{a}-7 \mathrm{~g}$. 
Prikaz 7a: ['xí:aa] (govorec 08mt). Laringalizacija lepo vidna med pribl. 420 in $630 \mathrm{~ms}$.

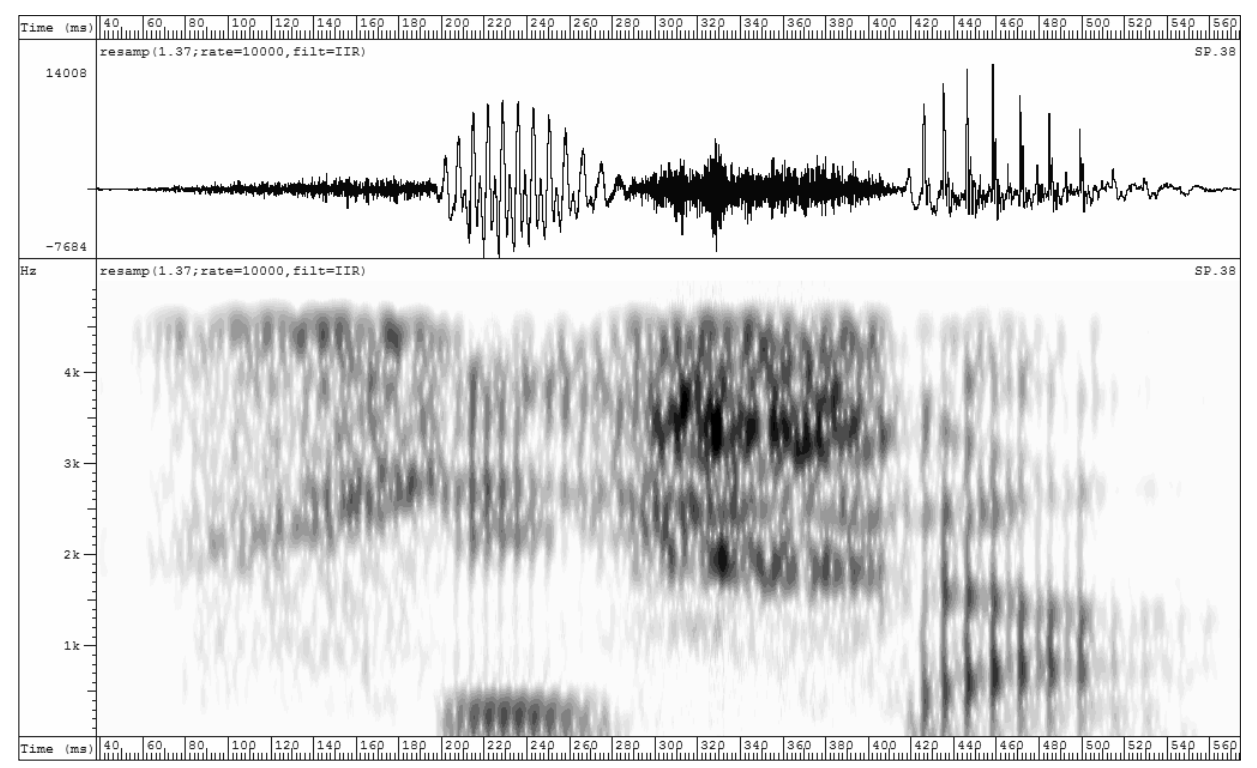

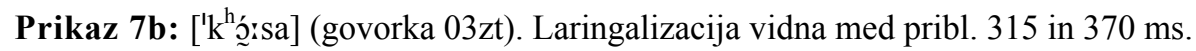

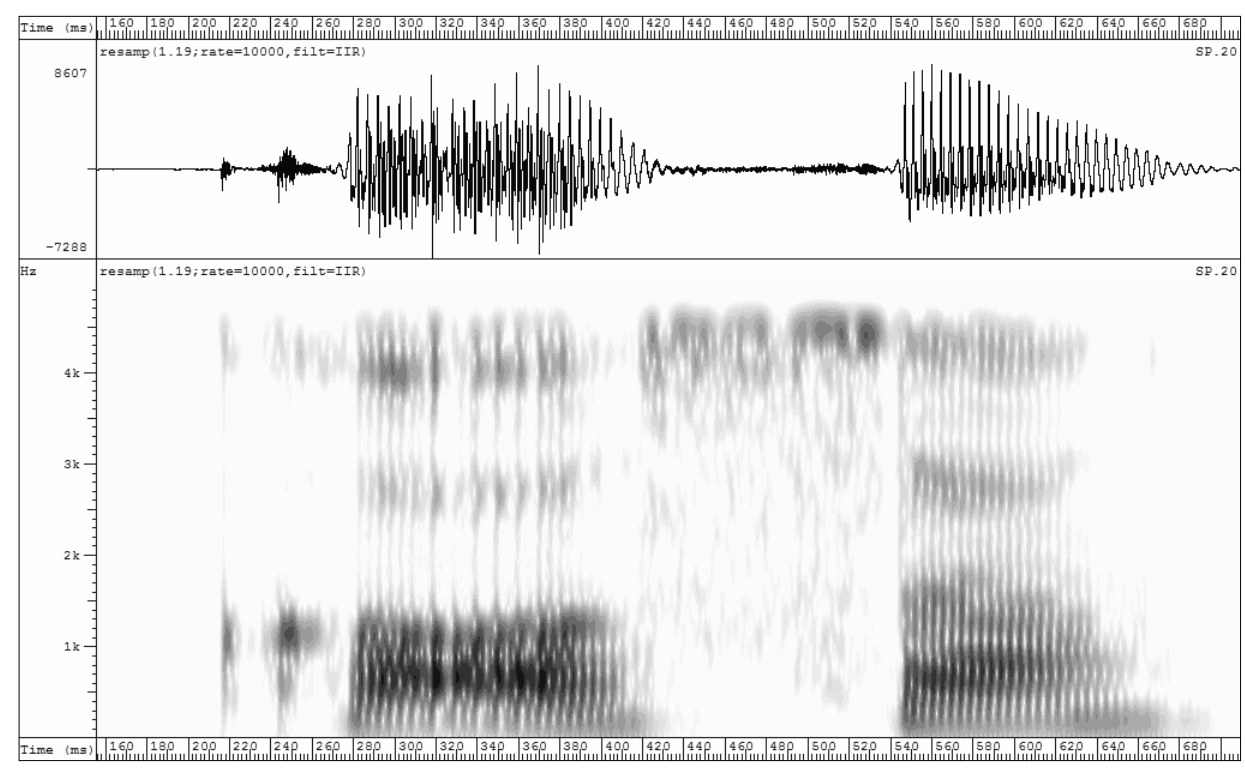


Prikaz 7c: ['kh a:pa] (govorka 02zn). Zelo izrazita laringalizacija med 580 in $630 \mathrm{~ms}$.

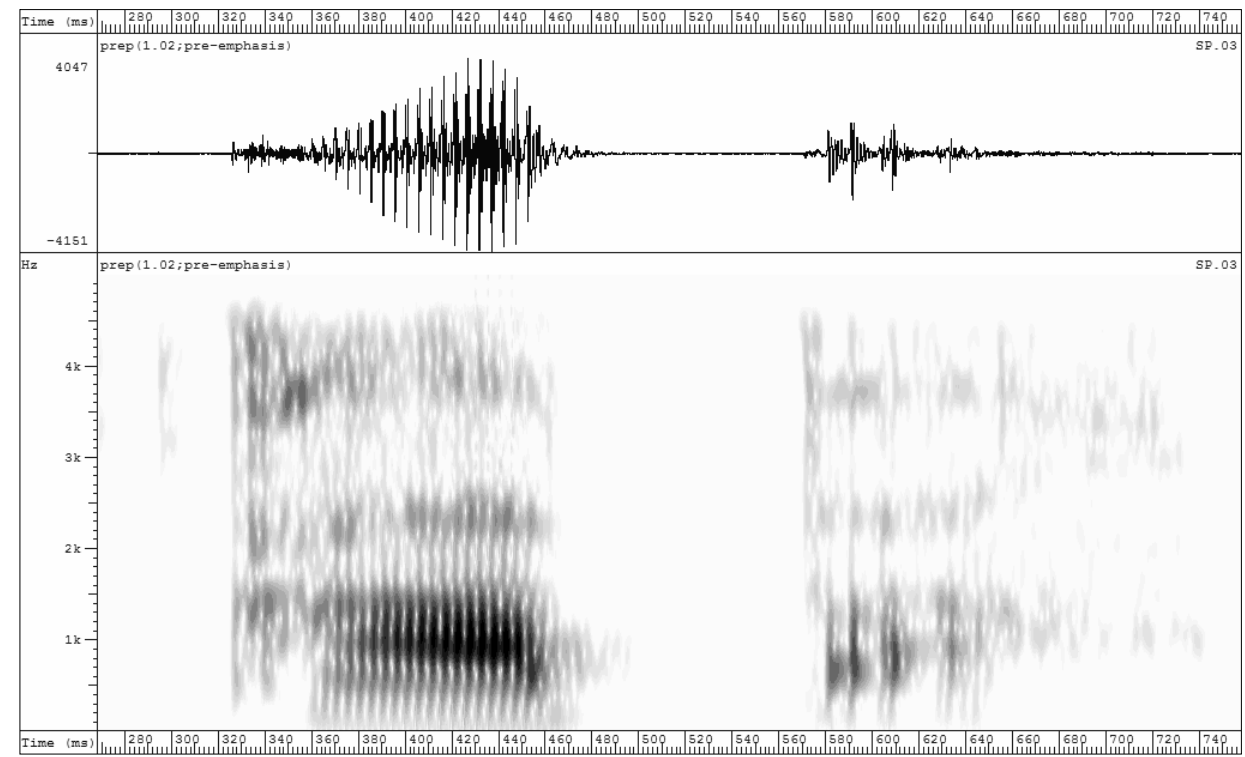

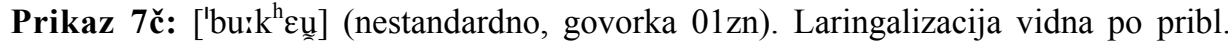
$420 \mathrm{~ms}$.

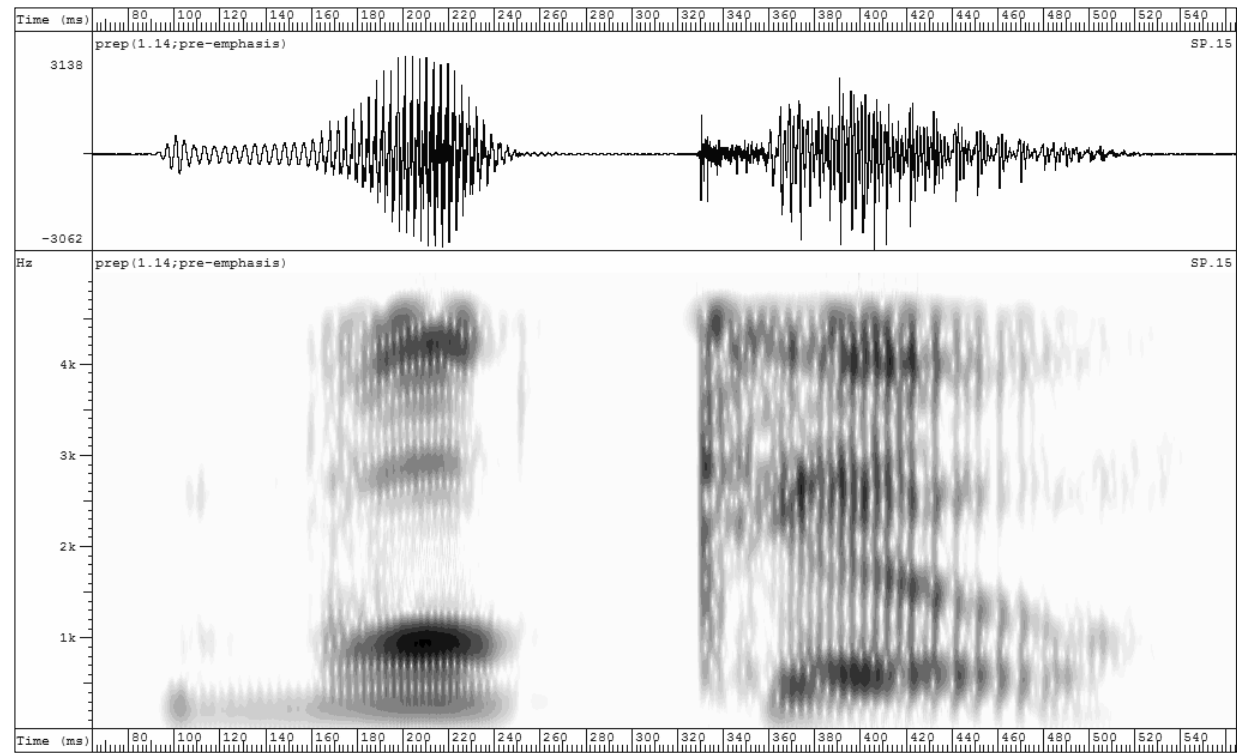


Prikaz 7d: (Vi ke)pate [pate] (govorka 04zt). Laringalizacija vidna med 590 in $650 \mathrm{~ms}$.

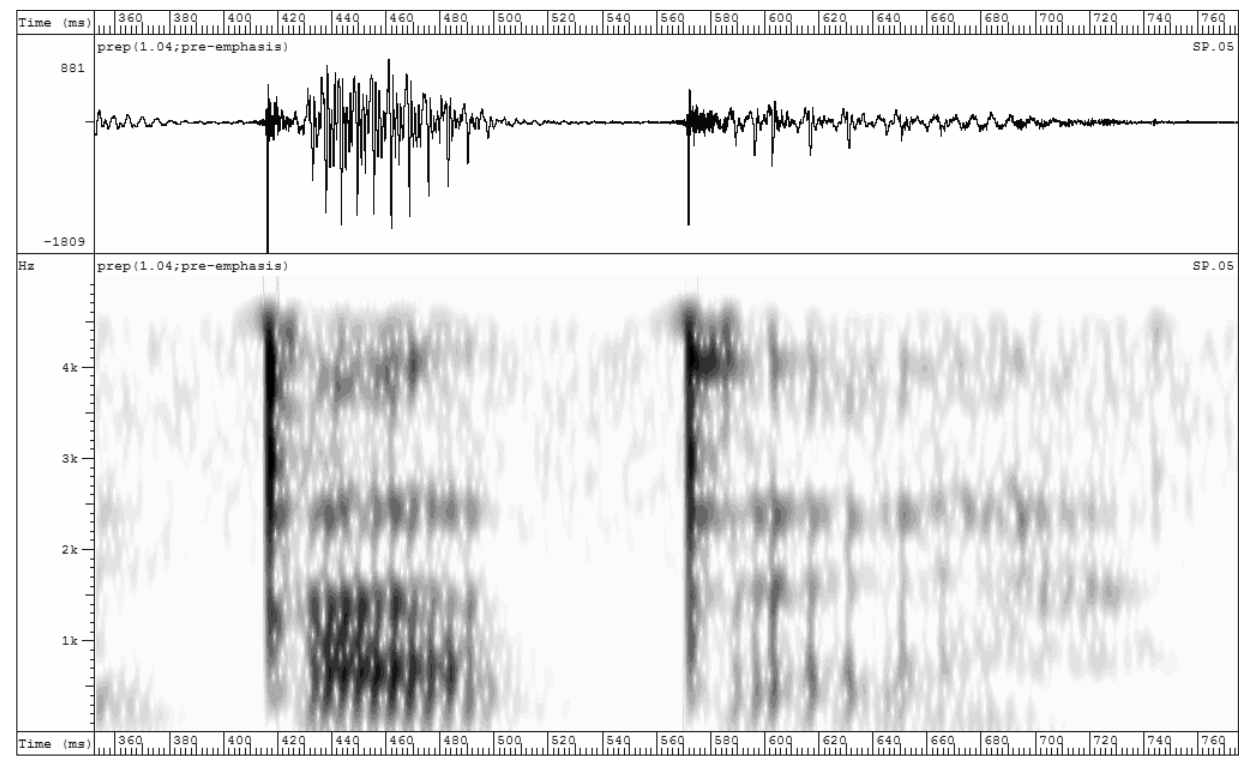

Prikaz 7e: [?ãy'k'è̀ta] (govorec 08mt). Laringalizacija jasno vidna od 870 ms dalje.

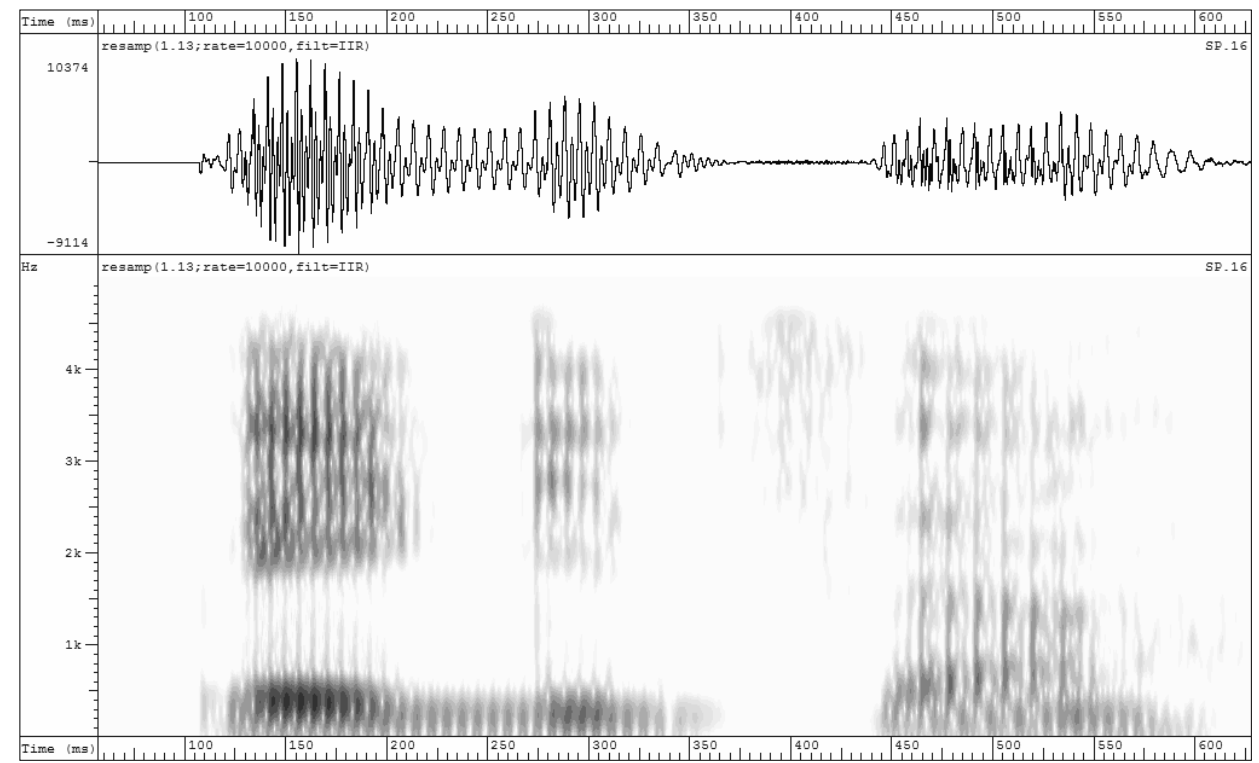


Prikaz 7f: ['pe:gitsa] (govorec 10mn). Laringalizacija vidna med 465 in 535 ms.

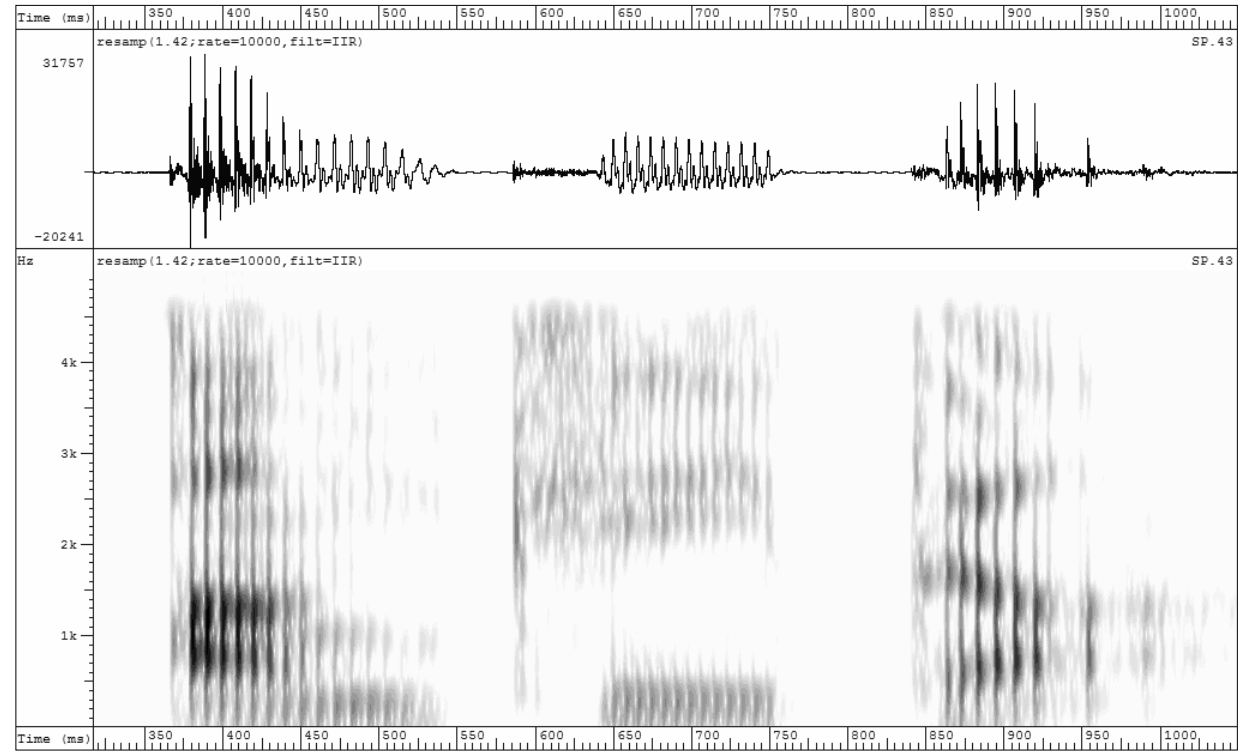

Prikaz 7g: ['k è:pate] (govorec 08mt). Laringalizacija vidna za [a] (765-840 ms) in za [e] (940 in dalje).

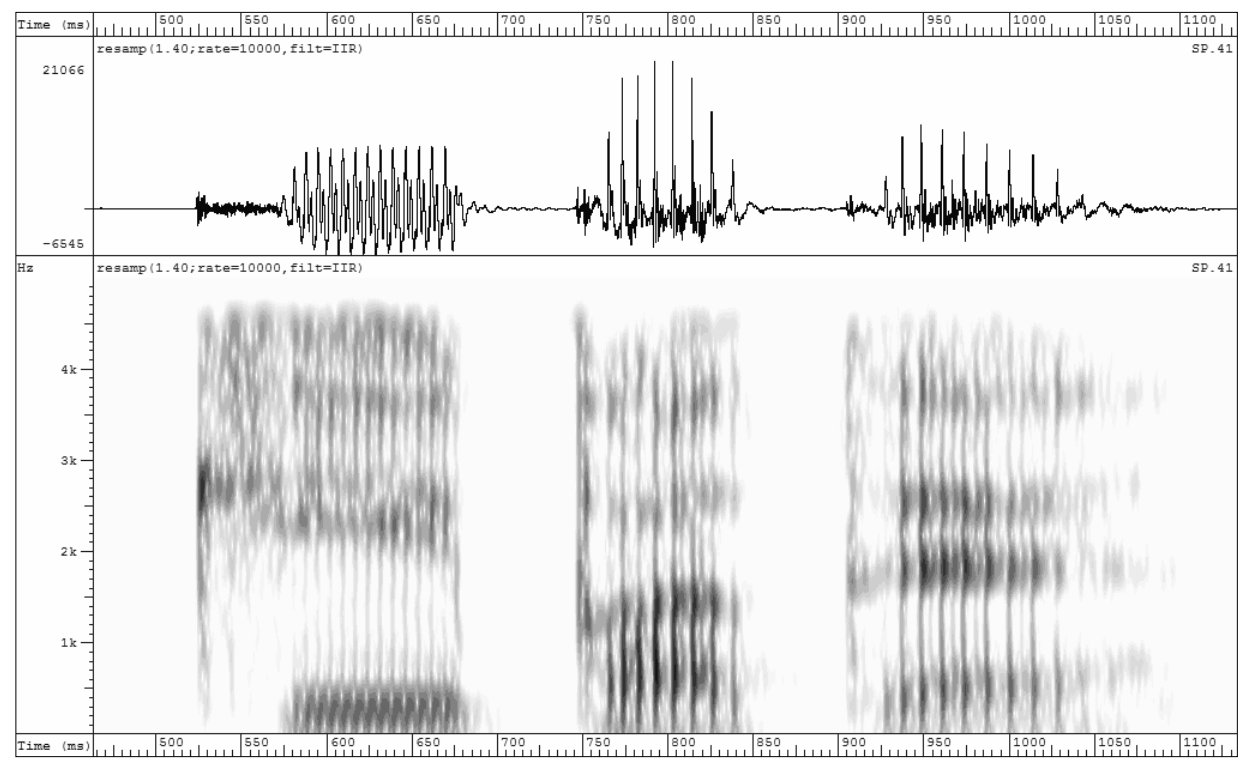


Dosedanje fonetične študije so ta tip laringalizacije povezovale z nizkim tonom kot posledico leksikalnega tonskega poteka ali stavčne intonacije. Raziskave tonskih jezikov so potrdile, da se hripavi glas povezuje z nizkim oz. nizkim padajočim tonom (npr. za mandarinsko kitajščino Belotel-Grenié in Grenié 2004, za hmonščino Huffman 1987 in tam dalje, ali splošnejši viri za švedščino, latvijščino, gl. Ladefoged 1971, Ladefoged in Maddieson 1996), zato ni razloga, da to ne bi veljalo za slovenščino, pri čemer je seveda treba upoštevati še nekatere druge prozodične dejavnike.

V nadaljevanju bom zato ta, najpogostejši tip laringalizacije v gradivu 1 (385 pojavitev) poskušal opredeliti glede na spremenljivke, kot so število zlogov, naglasno mesto in tonem (kontrastivno za tonemske in netonemske govorce). Ker je bilo gradivo sestavljeno posebej glede na te tri kriterije, lahko tu pričakujemo bistveno bolj uravnotežene rezultate kot pri vzglasni laringalizaciji (večina enot gradiva je imela enostavni zlogovni vzorec $\mathrm{CV}$ ). Seveda je treba upoštevati, da podatki zaradi izoliranega položaja niso povsem primerljivi s stanjem v tekočem govorjenem jeziku. Podatki o laringalizaciji so tabelarično predstavljeni v prikazu 8.

Prikaz 8: Dvo- in trizložnice z dolgim naglašenim samoglasnikom z nevzglasno laringalizacijo $\mathrm{v}$ gradivu 1 .

\begin{tabular}{|c|c|c|c|c|c|c|}
\hline & & & $\begin{array}{l}\text { ZLOŽNICE } \\
\text { onemsko }\end{array}$ & & tonemsko & skunai \\
\hline & & akut & cirkumfleks & akut & cirkumfleks & sкupa] \\
\hline \multirow{2}{*}{ paroskitona } & 1. zlog & 3 & 3 & 1 & 5 & 12 \\
\hline & 2. $z \log$ & 9 & 21 & 25 & 22 & 77 \\
\hline \multirow{2}{*}{ oksitona } & 1. $z \log$ & 0 & 2 & 1 & 1 & 4 \\
\hline & 2. $z \log$ & 3 & 3 & 1 & 0 & 7 \\
\hline \multirow[t]{2}{*}{ skupaj } & & 15 & 29 & 28 & 28 & 100 \\
\hline & & $\begin{array}{r}\text { TRI } \\
\text { tc } \\
\text { akut }\end{array}$ & $\begin{array}{l}\text { ZLOŽNICE } \\
\text { onemsko } \\
\text { cirkumfleks }\end{array}$ & $\begin{array}{r}\text { net } \\
\text { akut }\end{array}$ & $\begin{array}{l}\text { tonemsko } \\
\text { cirkumfleks }\end{array}$ & skupaj \\
\hline \multirow{3}{*}{ proparoksitona } & 1. zlog & 3 & 4 & 0 & 5 & 12 \\
\hline & 2. $z \log$ & 2 & 2 & 6 & 7 & 17 \\
\hline & 3. $z \log$ & 37 & 29 & 40 & 34 & 140 \\
\hline \multirow{3}{*}{ paroksitona } & 1. zlog & 1 & 2 & 1 & 1 & 5 \\
\hline & 2. $z \log$ & 6 & 1 & 1 & 2 & 10 \\
\hline & 3. $z \log$ & 13 & 27 & 34 & 21 & 95 \\
\hline \multirow{3}{*}{ oksitona } & 1. zlog & 0 & 0 & 0 & 0 & 0 \\
\hline & 2. $z \log$ & 0 & 2 & 0 & 1 & 3 \\
\hline & 3. $z \log$ & 0 & 1 & 1 & 1 & 3 \\
\hline skupaj & & 62 & 68 & 83 & 72 & 285 \\
\hline
\end{tabular}

Število zlogov. V enozložnicah ni primerov z laringalizacijo (razen vzglasni tip), pri čemer je treba upoštevati, da je $\mathrm{v}$ gradivu 1 najmanj primerov enozložnic (primeri naraščajo eksponentno s številom zlogov) - podobno je bilo ugotovljeno npr. še za 
mandarinsko kitajščino (Belotel-Grenié in Grenié 2004), finščino (Ogden 2001) in angleščino (npr. Redi in Shattuck-Hufnagel 2001). Število laringaliziranih enot se z naraščanjem števila zlogov hitro povečuje: daljša, ko je beseda, veliko večja je verjetnost, da bo kateri izmed njenih segmentov izgovorjen $s$ hripavim glasom. Takšno stopnjevanje gre vsaj v dve smeri: verjetnost, da bo laringalizacija prisotna zaradi prozodičnih dejavnikov meje, je statistično značilno večja pri daljših enotah oz. s tem povezanimi končnimi intonacijskimi položaji (prim. Umeda 1978, Dilley idr. 1996, zlasti pa Redi in Shattuck-Hufnagel 2001).

Prikaz 9: Število laringaliziranih segmentov v enotah gradiva glede na naglasno mesto in tonem za dvozložnice. Bistveno prevladujejo pojavitve laringaliziranih paroskiton v ponaglasnem zlogu. Statistično značilna je tudi razlika med akutiranimi in cirkumflektiranimi enotami pri tonemskih govorcih (2. in 6. stolpec).

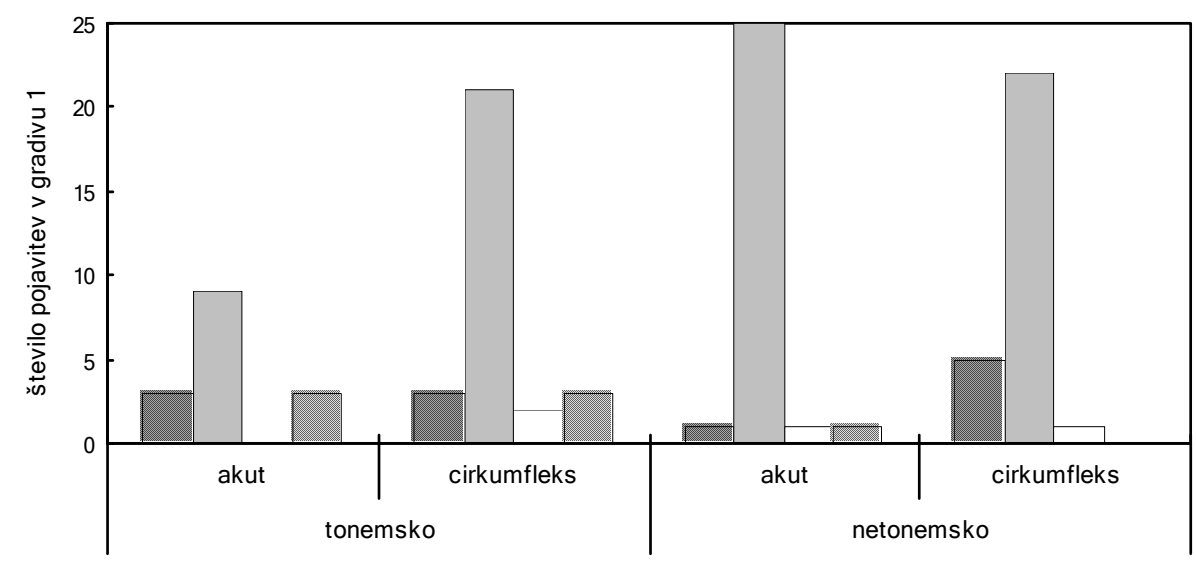

Đ paroskitona: naglašeni zlog $\square$ ponaglasnizlog $\square$ oksitona: prednaglasni zlog $\boxminus$ naglašeni zlog

Naglasno mesto. Iz prikaza 8 je jasno razvidno, da je največ laringaliziranih po- in poponaglasnih zlogov oz. samoglasnikov, kar velja ne glede na tonemskost govorcev. Oksitona so laringalizirana bistveno redkeje, ne glede na število zlogov v besedi. Videti je, da se laringalizacija ravna po dveh zakonitostih, ki součinkujeta: prevlado laringaliziranih izglasnih zlogov je mogoče pojasniti s težnjo po laringalizaciji konca intonacijske enote, ki jo ugotavljajo že študije za druge jezike (prim. navedenke zgoraj). Druga zakonitost, ki bi pojasnila odvisnost laringalizacije nevzglasnega tipa od naglasnega mesta, je izrazita redkost laringalizacije naglašenega in prednaglasnih zlogov (za finščino, denimo, so ugotovitve podobne: naglašeni zlogi so statistično značilno redkeje izgovorjeni s hripavim glasom, prim. Ogden 2001). Oboje je lepo vidno iz histogramov v prikazih 9 (dvozložnice) in 10 (trizložnice). Za kakršno koli nadaljnje ugotavljanje odvisnosti laringalizacije in naglasnega mesta je gradivo premalo obsežno.

Tonem. Pri opazovanju vpliva tona na laringalizacijo sem izločil kratke naglašene samoglasnike, saj so zelo redko laringalizirani (med dvozložnicami tako ni niti enega primera), kar je seveda povezano tudi z relativno redkostjo laringalizacije naglašenih in prednaglasnih zlogov. Podatki o dvo- in trizložnicah so statistično dovolj obsežni le za 
trditve o zadnjih zlogih. Število laringaliziranih tretjih zlogov je načeloma večje pri akutiranih kot pri cirkumflektiranih enotah in ta razlika ni odvisna od tega, ali so govorci tonemski ali ne. Statistično značilna razlika med obema skupinama pa je pri akutskih paroksitonih (dvo- in trizložnic): pri tonemskih govorcih je opaziti precej nižji delež laringalizacije $\mathrm{v}$ ponaglasnem zlogu akutiranih besed (ti podatki so poudarjeni $\mathrm{v}$ prikazu 8). To pomeni, da je tonska višina takih ponaglasnih samoglasnikov še nižja, kot če bi bili izgovorjeni modalno, kar je povezano tudi z morebitnim končnim položajem $\mathrm{v}$ intonacijski enoti. Vsekakor gre za razliko, $\mathrm{v}$ kateri se skupini tonemskih in netonemskih govorcev bistveno drugačni. Velja torej, da se laringalizacija povezuje $\mathrm{z}$ nizkim tonom: ponaglasni zlog pri akutu je statistično značilno $(p<0,005)$ redkeje laringaliziran v primerjavi s cirkumfleksom. Dopolnilna razlaga vključuje tudi dejstvo, da so slovenski akuti v večini narečij izgovorjeni $\mathrm{z}$ večjo jakostjo $\mathrm{v}$ ponaglasnem zlogu, kar so potrdili tudi preliminarni rezultati analize tonemskih minimalnih parov v slovenščini; nekatere izmed dosedanjih eksperimentalnofonetičnih raziskav slovenske tonematike so si sicer vprašanje jakosti zastavile, niso pa ga obravnavale, prim. Vodušek 1961, Neweklowsky 1973, Toporišič 1967, 1968, 1989, Srebot Rejec 1988, 2000.

Prikaz 10: Število laringaliziranih segmentov v enotah gradiva glede na naglasno mesto in tonem za trizložnice. Prevladujejo pojavitve laringaliziranih zadnjih zlogov, če so nenaglašeni. Statistično značilna je tudi razlika med akutiranimi in cirkumflektiranimi enotami $v$ ponaglasnem zlogu paroksiton pri tonemskih govorcih, medtem ko je razlika pri netonemskih ravno nasprotna, vendar predvidljiva (prim. svetlo in temno sive stolpce). Segmenti v naglašenem in prednaglasnem zlogu so izrazito redki $(<10$ pojavitev).

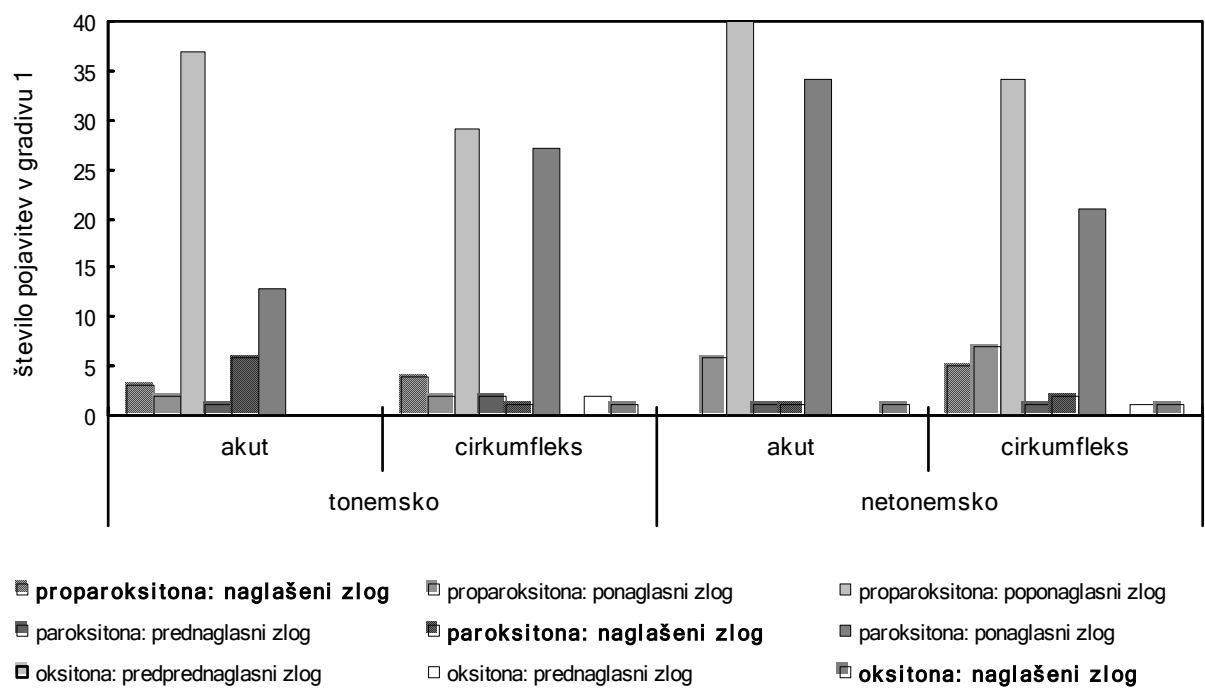

Če torej povzamem: verjetnost, da bo neki segment oz. njegov del (zlasti to velja za samoglasnike) laringaliziran, narašča s številom ponaglasnih zlogov. Laringalizirani 
ponaglasni zlogi pri akutu so statistično značilno redkejši kot pri cirkumfleksu, seveda samo za tonemske govorce.

\subsection{Laringalizacija tipa 3}

Na posnetkih je bilo tudi kar nekaj pojavitev, ki jih eksperiment ni posebej predvidel. Sem spadajo različna ponavljanja, popravljanja, napake pri branju, oklevanja, medmeti, komentarji ipd. Takšne enote so zelo pogosto izgovorjene s hripavim glasom v celoti. Sistemsko je s hripavim glasom v slovenščini izgovorjen medmet [2] (realiziran tudi

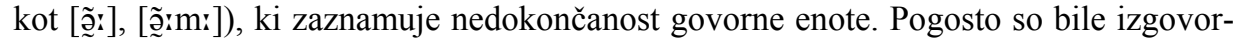
jene $\mathrm{s}$ hripavim glasom še enote

(2) $\quad v$ redu C [u'rè̀du] - okej C ['ò:kęi]

$$
\text { ja } \mathrm{C}[\mathrm{ja}:]-n e[\mathrm{n} \varepsilon]
$$

ki so v tem eksperimentu vse rabljene v metajezikovni funkciji. Lastnost takih primerov $\mathrm{v}$ fonetičnem smislu je nenehno (ali pa pretežno) prisoten hripavi glas. Značilen primer tega tipa laringalizacije je v prikazu 11.

Prikaz 11: Primer laringalizacije v enoti pardon C ['pàirdõn] (govorka 03zt). Viden je značilni potek: hripavi glas je prisoten v celotnem poteku.

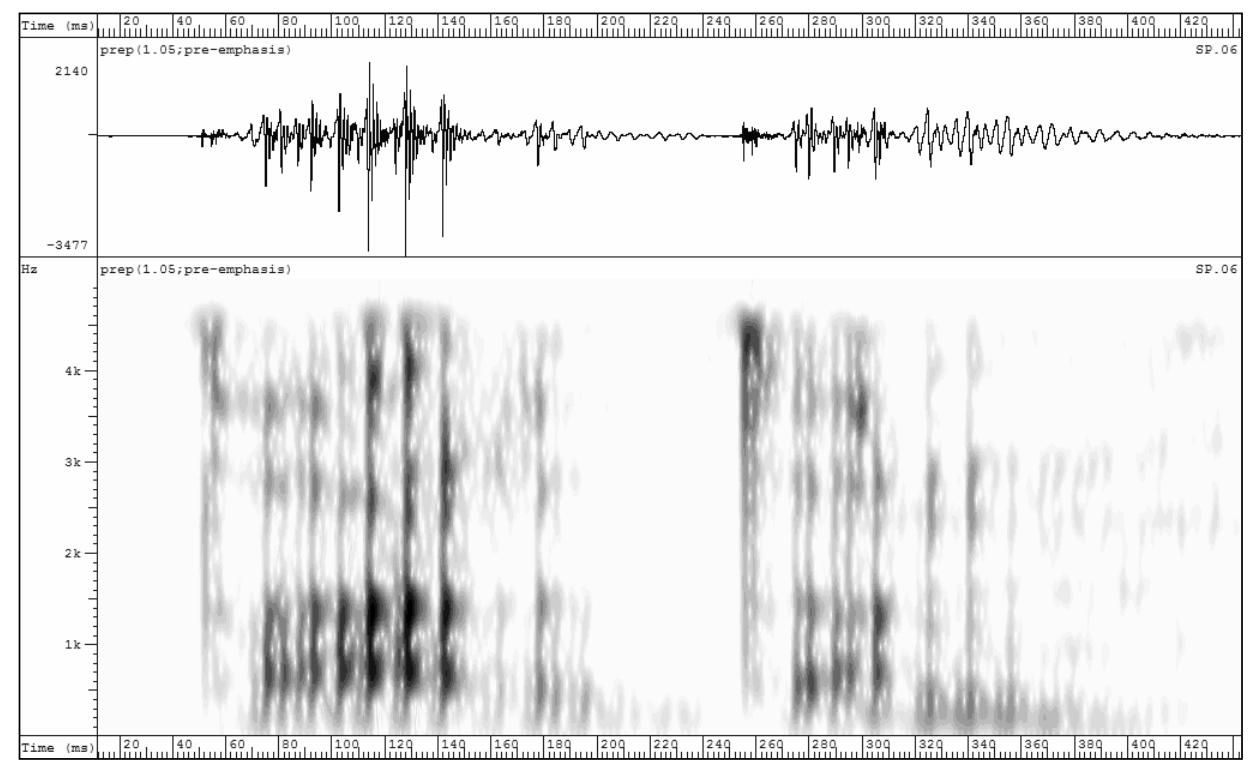

\section{Rezultati: narečni podatki}

Iz narečnega gradiva je bilo izločenih zelo jasnih 61 enot $(11,4$ \% izsečkov, kar je primerljivo s stanjem za standardno slovenščino). V nadaljevanju bom skušal zlasti nevzglasno fonacijo preveriti tipološko in glede na toneme, katerih fonetična realizacija je, vsaj kar se tiče osnovne frekvence v primerjavi z drugimi slovenskimi narečji, kar dobro preučena (Vodušek 1961, Neweklowsky 1973, Jurgec 2005a): razlike med akutom in cirkumfleksom so zelo izrazite, bistvena je $\mathrm{v}$ dosedanjih raziskavah relativna 
tonska višina. Pri obravnavani govorki so te razlike še nekoliko večje, na kar vpliva dokaj pogostna falzetna fonacija (ki jo govorka rabi bodisi za celotno govorno enoto oz. njen daljši del bodisi leksikalno glede na ton, natančno distribucijo pa bo treba še preučiti, saj je pogostna tudi pri nekaterih drugih govorkah istega govora).

\subsection{Laringalizacija tipa 1}

Glotalni zapornik je v ziljščini, kakor se govori v Kanalski dolini, kar pogost: ['Pàrútar] 'avto', [?aß'ftì:rəx] 'ob štirih', čeprav nikakor ne splošen. Kot je bilo ugotovljeno že za druga koroška narečja (Neweklowsky 1970, Priestly 1976, 1980), kjer je fonološki status / $/$ / popolnoma drugačen, lahko prihaja do variantne uresničitve, posebej če je meja $\mathrm{V}]_{\mathrm{b}}[\mathrm{V}$ :

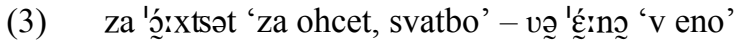

Lahko torej rečemo, da se laringalizacija alofonsko pojavlja $\mathrm{v}$ samoglasniških vzglasjih tudi v ziljskem govoru Kanalske doline, čeprav natančna pogostnost in morebitne distribucijske lastnosti (̌̌e) niso znane.

\subsection{Laringalizacija tipa 2}

V obravnavanem govoru je ta tip laringalizacije zelo pogosten. Najbolj izraziti so primeri na koncu intonacijske enote, kjer je hripavi glas tudi najpogostnejši. Načeloma so se potrdile ugotovitve za standardno slovenščino: naglašeni samoglasniki so redko laringalizirani, laringalizacija je pogostnejša pri daljših besedah. Zanimivo je, da je v gradivu 2 najobičajnejši tip laringalizacije povezan $\mathrm{z}$ akutom: akutirana proparoksitona in paroksitona so $\mathrm{v}$ končnem stavčnem položaju najpogosteje realizirana tako, da je laringaliziran zadnji zlog, čeprav so seveda tudi nasprotni primeri. Te akutirane besede imajo izrazito nizko intonacijo, čeprav je v končnem položaju za akutirane besede $\mathrm{v}$ tem govoru bolj pogostna visoka, visoka padajoča, visoka rastoče-padajoča. Takšen primer je v prikazu 12. Zaradi tega je določitev tonema v dvomljivih primerih problematična. Nekaj drugih primerov (glede na naglasno mesto, kjer prevladujejo paroksitona): ${ }^{16}$

(4.1) proparoksitona: ne 'viõm pa'vé:ðat९ِ $\downarrow \|$ 'ne znam povedati, ne vem' -

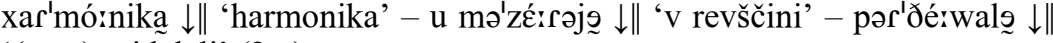
'(smo) pridelali' $(2 \mathrm{x})$

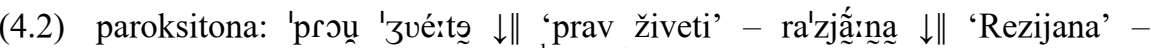

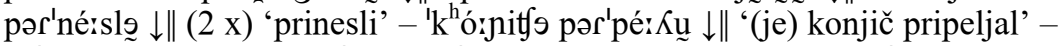
na'ré:dlø $\downarrow \|$ 'naredili' - 'mras pa'zí:m@ $\downarrow \|$ 'mraz (je) pozimi' - 'zná:t९ $\downarrow \|(2$ x) 'znati' - kər 'xó:tfte $\downarrow \|$ 'kar hočete' - tote 'jó:pts\& $\downarrow \|$ 'te jopice' -

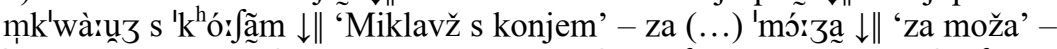

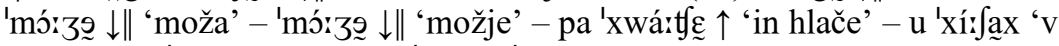
hišah' - w i'tá:Ki 'v Italiji' - 'tsìwa 'zírma $\downarrow \|$ 'vso zimo'

(4.3) oksitona: je bwo 'fár:in $\downarrow \|$ ‘bilo je dobro' - je bwo 'fá্:in $\uparrow \|$ 'dobro je bilo' -

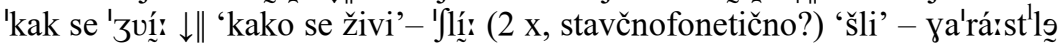
$\downarrow \|$ 'odraščali'

\footnotetext{
${ }^{16}$ Navajani so tudi nekateri primeri iz dodatnega gradiva, omenjenega v razdelku 5, zato številčno ne ustrezajo v razdelku 7 predstavljenim deležem.
} 
Prikaz 12: Zadnja beseda enote [z 'nì:mi 'zué:ţ̃ $\downarrow$ ] 'z njimi živeti' iz gradiva 2 je realizirana $\mathrm{z}$ izrazito nizko intonacijo (prim. potek $f_{0}$ ) v ponaglasnem zlogu, čeprav je akutirana. Laringalizacija se začne pri okoli $1250 \mathrm{~ms}$ posnetka, najbolj jasna je med 1430 in 1570 ms ([き]). Značilni potek, zlasti oscilogramski.

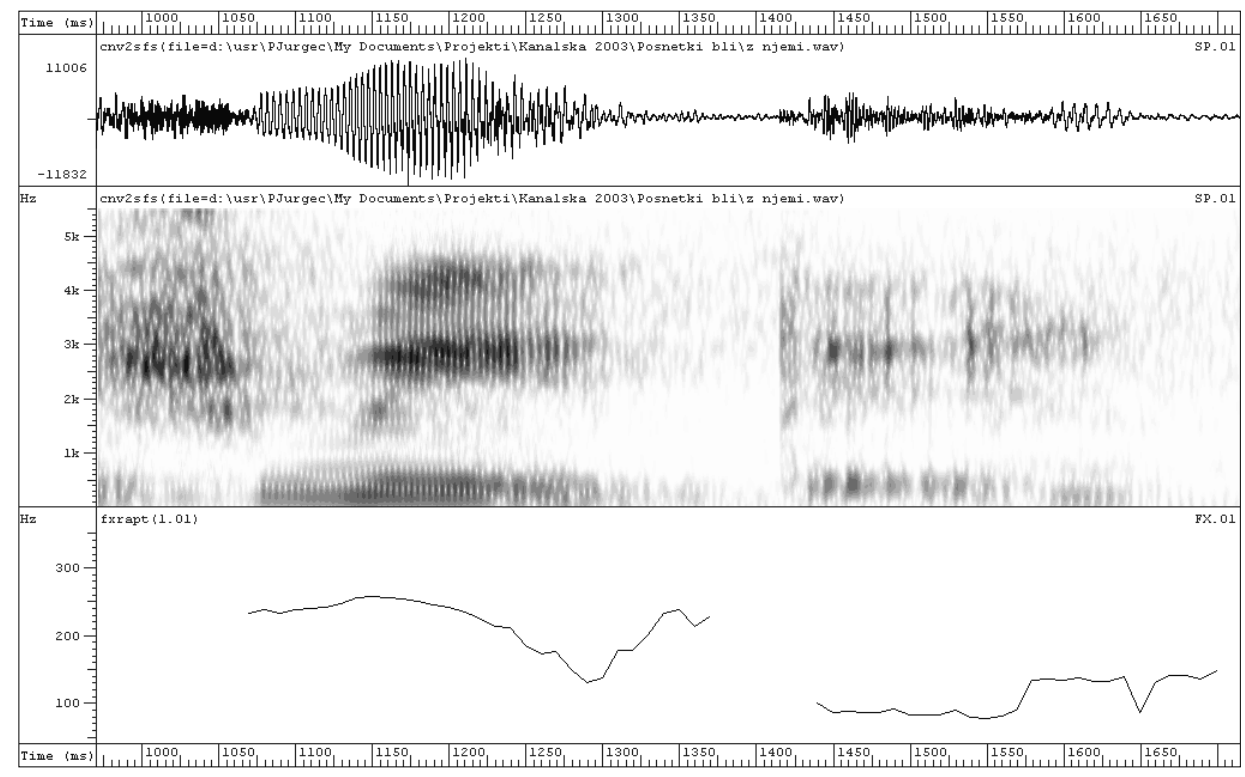

Težnja po laringalizaciji pri akutih ni splošna, saj obstajajo tudi nasprotni primeri laringalizacije cirkumflektiranih ali kratkih naglašenih tipov, tudi oksiton, ki jih je vseeno bistveno manj. Padajoča oz. nizka (...) intonacija je tu povsem regularna. Nekaj primerov:

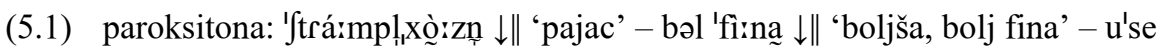

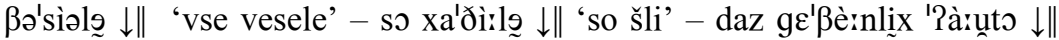

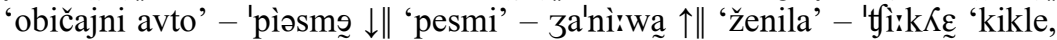
krila' - 'nòty 'drùxigga $\downarrow \|$ 'nič drugega'

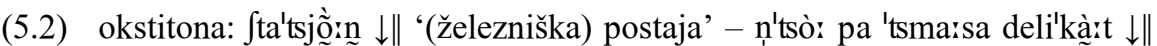
'danes, zdaj pa (so) preveč občutljivi' - na'rè̀:t $\downarrow \|$ 'narejen'

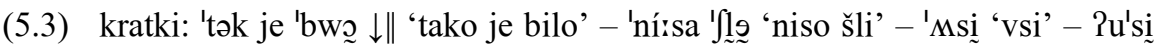
'vsi' - k 'nã̃m 'k nam'

Laringalizacijo tipa 2 v narečnem gradivu lahko povežemo predvsem s končnim intonacijskim položajem pred pavzo.

\subsection{Laringalizacija tipa 3}

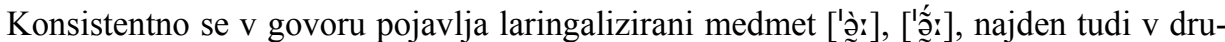
gih posnetkih govora Kanalske doline. V primerjavi s standardnim se dodatno bistveno pogosteje pojavlja še nazalizacija. 


\section{Komentar in tipološke posledice}

$\mathrm{V}$ gradivu sem laringalizacijo razdelil na tri tipe glede na omejitve, ki jih je narekovalo gradivo $1, \mathrm{tj}$. izolirano izgovorjene besede. Pri tem sem združeval več hkratnih, a tudi nasprotnih spremenljivk, pri katerih je laringalizacija verjetnejša $\mathrm{v}$ drugih jezikih. $\mathrm{V}$ tem razdelku bom te spremenljivke skušal ločiti in sistematizirati glede na ugotovitve drugje in seveda $\mathrm{v}$ tej raziskavi. $\mathrm{S}$ tem bodo nakazane tudi nadaljnje smeri za raziskave nemodalne fonacije $\mathrm{v}$ slovenščini.

Pregledna dela precej različno sistematizirajo pojavljanje laringalizacije $\mathrm{v}$ jezikih sveta, vendar so fonološke segmentne spremenljivke bržkone najbolj jasno razpoznavne. Največ primerov segmentnih kontrastov navaja Ladefoged s sodelavci v svojih raziskavah manj znanih in ogroženih jezikov sveta. Najredkejši so pri nezvočnikih, v zvezi s katerimi omenjajo zlasti čadske jezike, med njimi havščino 〈Hausa, HUA〉 (dalje gl. Ladefoged in Maddieson 1996: 53-55); pogostejša je opozicija pri zvočnikih, denimo pri severnoameriških indijanskih jezikih, npr. v kvakvalščini〈Kwakw'ala, KWK〉, montanski sališčini 〈Montana Salish, FLA〉, kolumbijski sališčini 〈Columbian Salish, COL〉, hupščini 〈Hupa, HUP〉. Jalapska mazateščina ima poleg kontrasta zveneči : nezveneči : laringalizirani nosniki še trojni (poleg modalnih in laringaliziranih še zamolkle) kontrast pri samoglasnikih. Podobno tudi v narečni sanlucaški zapoteščini 〈San Lucas Quiaviní Zapotec, MAA〉. Modalni in laringalizirani samoglasniki so tudi v burmanščini 〈Burmese, MYA〉. Prim. Ladefoged 1971, Ladefoged idr. 1988, Ladefoged in Maddieson 1996, Gordon in Ladefoged 2001, Ladefoged 2003. Seveda česa takega $\mathrm{v}$ slovenščini zelo verjetno ni najti.

Alofonsko se laringalizacija namesto [?] pojavlja v pogovorni nemščini, ko zamenja standardne /t/, /k/ ali /d/, npr. v Beamten /bə'?amm/ (Kohler 1994). Prim. podobno še za [?] v ameriški angleščini (Patterson in Connine 2001). V pogovorni ljubljanščini najdemo izrazite primere pri tvorjenih števnikih: devetdeset [da'vèəsət]][da'vèəsət], šestdeset ['Jèəasət], sedemdeset ['séãsət]; čeprav tudi pridem ['príĩ̃m].

Nadsegmentni fonološki vidik je prisoten kot povezava med določenim tonom (bodisi $\mathrm{v}$ jezikih $\mathrm{z}$ leksikalnim tonom ali tonom $\mathrm{v}$ ožjem pomenu) in laringalizacijo. $\mathrm{V}$ švedščini, denimo, se laringalizacija povezuje s ponaglasnim zlogom akcenta 1 (t. i. akutom), in sicer njegovim ponaglasnim zlogom (Verhoeven, nav. po Laver 1994: 464). V latvijščini je laringalizacija nadsegmentna lastnost rastoče-padajočega tona 〈lauzta intonacija〉. Danski stød je dobro znana samostojna nadsegmentna lastnost (za fonetično analizo gl. Fischer-Jørgensen 1989, prim. tudi Grønnum in Basbøll 2001 in tam dalje). $\mathrm{V}$ jezikih sveta je laringalizacija pogosto povezana $\mathrm{z}$ nizkim ali nizkim padajočim tonom, kot npr. v kitajščini (Belotel-Grenié in Grenié 2004 in tam dalje) in verjetno tudi v hmonščini (prim. Huffman 1987 in tam dalje). Laringalizacijo povezujejo tudi s tonogenezo (prim. Purcell idr. 1978, Hombert idr. 1979 in Greenberg 2004). V zvezi s slovenščino sem hotel dokazati povezavo med enim od tonov in laringalizacijo tipa 2 , vendar je precej verjetno, da je ta povezava samo fonetična, vsaj v obravnavanem narečju in v standardu. Še več, verjetno je to neločljivo povezano še z drugimi prozodičnimi dejavniki, najbolj različnimi stopnjami mej (prim. Lehiste 1965).

Prozodični dejavniki meje (intonacijske, besedne, zlogovne v tipu ]V in V][V) so prisotni tudi pri laringalizaciji tipa $1 \mathrm{v}$ pričujočem besedilu. Pravzaprav gre pri tem tipu laringalizacije za več neodvisnih dejavnikov, ki jih zaradi sestave gradiva ne moremo ločiti: vpliv meje izreka, meje intonacijske enote, besedne meje, skratka prozodične 
meje, in deloma tudi segmentno pogojeni dejavniki, zlasti kontekst (V)_V. Tudi dosedanje študije, ki se ukvarjajo največ $\mathrm{z}$ angleščino, združujejo te dejavnike. Allen (1970) ugotavlja, da samoglasniški niz na (besedni idr.) meji in značilni tonski potek vplivata na večjo pogostnost glotalnih zapornikov, Umeda pa (1978), da so individualne razlike, stil branja in težavnost besedila (uporaba redkih besed) pomembnejše od fonološkega konteksta (pri Allenu npr. odprtostna stopnja samoglasnika): glotalni zapornik (iz spektrogramov je videti, da gre tudi za hripavi glas in sorodno) je najpogostejši v samoglasniškem vzglasju prvonaglašenih polnopomenskih besed, če so po rabi redke, pri čemer so individualne razlike precejšnje. Nekoliko več glotalnih zapornikov je, kadar se predhodna beseda konča na samoglasnik, zelo redke so v nepolnopomenskih besedah. Pierrehumbert (1995) ugotavlja vpliv fraznega naglasa na vzglasno glotalizacijo (pogostnost, vrsta in značilnosti). Naglas ima bistveno večji vpliv na vzglasno glotalizacijo kot na glotalizacijo nezvenečih zapornikov v izglasju. Dilley idr. (1996) potrjujejo rezultate predhodnih raziskav Pierrehumbertove: glotalizacija (tj. hripavi glas, hrip, glotalni zapornik, tudi v obliki upada osnovne frekvence ali amplitude $)^{17}$ je veliko pogostejša na začetku intonacijske enote, četudi pred njo ni pavze ali glotalizacije predhodnega elementa, kar še dodatno poveča pogostnost glotalizacije. Dodatno na to vpliva še pri-

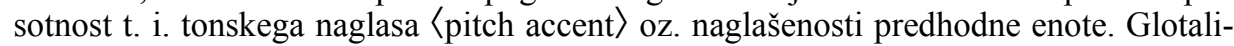
zacija je pogostejša pri besedah s samoglasniškim vzglasjem, sledi drsniško, nosniško, priporniško in zaporniško - razlika je statistično značilna pri vzglasjih ne na začetku intonacijske enote. Velike so individualne razlike $\mathrm{v}$ deležu in načinu glotalizacije (prim. o tem tudi druge vire v razdelku 4). Redijeva in Shattuck-Hufnaglova v svoji študiji (2001) ugotavljata glotalizacijo na intonacijski meji in na koncu izrekov, in sicer za štiri tipe glotalizacije (aperiodičnost, hrip, diplofonijo in glotalni škrip 〈glottal squak $\rangle){ }^{18}$ pri čemer potrjujeta dosedanje ugotovitve o precejšnji variabilnosti. Največji delež glotalizacije je na koncu izreka oz. na meji zaključenih intonacijskih enot. Hripavi glas je pogost označevalec prozodičnih mej, bodisi začetnih bodisi končnih, tudi v drugih jezikih, npr. v švedščini, finščini, češčini, srbščini/hrvaščini (Lehiste 1965, za finščino prim. še Ogden 2001) ali kitajščini (Belotel-Grenié in Grenié 2004).

Segmentni dejavniki so ponavadi alofonski, kot npr. v nemščini. Kohler (1994) je preučil morfološko odvisne pojavitve [?] v nemščini, pri čemer je v nasprotju s standardno rešitvijo ugotovil precejšnjo variantnost v realizaciji: hripavi glas $(27 \%$ enot $)$, tišina in hrip (27\%), glotalni zapornik (15\%) ali brez dokazov o nemodalni fonaciji (21\%). Glotalizacija je tudi sicer še posebej pogostna, kadar gre za mejo V $]_{\mathrm{m}}[\mathrm{V}$; tako tudi v zgoraj navedenih jezikih, poleg tega pa npr. še v hualtski mazateščini 〈Hua(u)lta Mazatec, HUA〉, Pike in Pike 1947, nav. po Ladefoged in Maddieson 1996: 74. To je bilo ugotovljeno tudi za slovenščino (Jurgec 2004a, 2005b). V gradivu 1 se [?] ali laringalizacija pojavlja v $30,2 \%$ vseh besed s samoglasniškim vzglasjem (laringaliziranih je 108 enot). Čeprav je pogostnost v spontanem govoru verjetno nižja (potrebne so

${ }^{17}$ Slednje je znano kot t. i. navidezna glotalizacija 〈»virtual glottalization«〉, prim. Dilley idr. 1996, Houde in Hillenbrand 1994. Na tem mestu naj opozorim tudi na glas iz gimščine 〈Gimi, GIM $\rangle_{\mathrm{v}}$ Ladefoged in Maddieson 1996: 76-77, ki je vsaj glede na akustični opis precej podoben navidezni glotalizaciji (avtorja ga označujeta z znakom [*]) - kontrast je fonemski.

${ }^{18}$ Glotalni škrip je glotalizacija nizke amplitude (jakosti) in visoke osnovne frekvence. 
nadaljnje raziskave tega tipa), gre še vedno za zelo velik delež, ki ga je treba pripisati tako meji $\mathrm{V}]_{\# \#[}\left[\mathrm{V}\right.$ kot najvišji prozodični meji, tj. meji izreka. ${ }^{19}$

Tu pa se začnejo pragmatične spremenljivke, ki tudi ugotovljeno vplivajo na pojavljanje oz. pogostnost laringalizacije. $\mathrm{V}$ angleščini tako laringalizacija $\mathrm{v}$ kombinaciji z nizko tonsko višino izraža konec posameznega izreka oz. govorne izmenjave (Laver 1980: 126). - Podobna je parajezikovna uporaba laringalizacije; v angleščini tako, če je uporabljena $\mathrm{v}$ celotnem izreku, izraža zdolgočaseno vdanost $\mathrm{v}$ usodo, $\mathrm{v}$ celtalščini 〈Tzeltal, TZH〉 (prošnjo za) pomilovanje in tožbo (n. m.), v totontepeškem jeziku miščini 〈Mixe, MTO〉 pa opravičilo ali ponižno prošnjo (Laver 1994: 196 in tam dalje). Podobno velja za parajezikovno funkcijo drugih vrst fonacije, npr. šepetanja, ki v angleščini ali slovenščini izraža zaupnost, a tudi strah. Čeprav se zdi taka raba fonacije univerzalna, je bržkone kulturno pogojena. - V gradivu slovenščine je laringalizacija tipa 3 parajezikovna in tudi pragmatična; rabi se $\mathrm{v}$ medmetih, ki izražajo neprekinjenost, nekončanost govorne enote, izreka in hkrati tudi težave pri ubesedovanju ter posledično lahko prošnjo za pomoč. Tip pardon ipd. izraža tako opravičilo kot metajezikovno pojasnilo k izrečenemu. Sicer se hripavi glas lahko rabi tudi za ironizacijo povedanega.

Zelo slabo je raziskana sociolingvistična raba laringalizacije, ki sporoča pripadnost določeni socialni skupini ali podskupini (prim. Redi in Shattuck-Hufnagel 2001). $\mathrm{V}$ edinburški angleščini je povečana raba hripavega glasu povezana $\mathrm{z}$ višjim družbenim položajem (Ní Chasaide in Gobl 1997: 457), kar velja tudi za köbenhavnsko danščino (Laver 1980: 196). Sem lahko sodi tudi razlika med moškimi in ženskimi govorci (prim. tudi Holmerg idr. 1988, Klatt in Klatt 1990, Hanson 1997 in Hanson in Chuang 1999, Redi in Shattuck-Hufnagel 2001), če je v nekem okolju splošna. V zvezi s slovenščino lahko govorimo o dveh tipih laringalizacije, ki je odvisna od osnovne frekvence: pri moških govorcih z nizko osnovno frekvenco se laringalizacija pojavlja zelo pogosto v (končni) padajoči intonaciji; pri ženskih govorkah te odvisnosti ni, saj se laringalizacija pojavlja pogosto tudi tam, kjer osnovna frekvenca ni zelo nizka; laringalizacija je $\mathrm{v}$ tem tipu povezana $\mathrm{z}$ glotalizacijo, posameznimi neregularnimi glotalnimi pulzi, diplofonijo ipd. - to pa so že individualne razlike, ki sodijo med zunajjezikovne okoliščine govora (Holmberg idr. 1993) in naprej v forenzično fonetiko, foniatrijo in govorno prepoznavanje.

\section{Sklep: nadaljnje raziskave}

Nadaljnje raziskave laringalizacije v slovenščini lahko potekajo v več smeri. Natančneje je treba določiti vpliv prozodičnih spremenljivk na pogostnost laringalizacije, za kar so najprimernejše označene računalniško berljive zbirke govora, ki jih za slovenščino obstaja že kar nekaj (gl. Žganec Gros idr. 2003). Rezultati take raziskave bodo zanimivi

\footnotetext{
${ }^{19}$ Če podatke primerjamo s tistimi za selški govor v Priestly 1980, se hitro pojavi vprašanje, ali je zlasti vzglasni refleks za psl. */k/ v delu podjunskega in rožanskega narečja sploh še realiziran na površinski fonetični ravni: saj ni prav nič pogostejši od /R/v standardni nemščini in le malo pogostejši kot / $/$ / oz. laringalizacija v standardni oz. koroški narečni slovenščini (prim. razdelka 6.1 in 7.1 tega besedila). Poleg tega je v jezikih, kjer je / $/$ / fonemski, npr. v havajščini (Ladefoged in Maddieson 1996: 74), ta redkeje podvržen variantnosti (prim. tudi podatke za libanonsko arabščino, n. d., 75), povsem drugače kot v selškem govoru (prim. Priestly 1980, 1976, Neweklowsky 1970). Seveda gre lahko v tem primeru še za druge, neraziskane dejavnike.
} 
predvsem zaradi primerjave s podatki iz jezikov z več govorci. Druga smer raziskovanja lahko zajame slovenska narečja in pojavljanje laringalizacije $v$ njih. Prav tako še ni dokončno rešeno vprašanje [?] $\mathrm{v}$ delu podjunskega in rožanskega narečja in nasploh $\mathrm{v}$ slovenščini (npr. kontrastivno $\mathrm{z}$ nemščino), $\mathrm{s}$ čimer mislim predvsem na njegovo distribucijo in pogostnost. Tudi razmerje med nadsegmentnimi lastnostmi in laringalizacijo še ni pojasnjeno, saj so potrebne tudi sodobnejše, polavtomatsko in avtomatsko zasnovane raziskave tona in intonacije $\mathrm{v}$ slovenščini, tudi $\mathrm{v}$ povezavi $\mathrm{z}$ intenziteto. Akustične in artikulacijske študije laringalizacije $\mathrm{v}$ obliki hripa, hripavega glasu ali glotalnega zapornika na podlagi slovenščine bi lahko prispevale $\mathrm{k}$ razumevanju teh pojavov $\mathrm{v}$ jezikoslovni fonetiki nasploh. Seveda bi bile zaželene tudi analize drugih vrst nemodalne fonacije, zlasti zasoplega glasu, falzeta in šepeta. Čeprav so ti pojavi znani iz nekaterih narečij, njihova (fonološka, fonetična, pragmatična, parajezikovna, sociolingvistična in zunajjezikovna) vloga sistematično še ni raziskana. Vprašanje fonacijskih možnosti - tudi v slovenščini - je izrazito multidisciplinarno.

\section{Literatura}

Allen 1970 - Allen, J., 1970. The glottal stop as a junctural correlate in English. Journal of the Acoustical society of America XL/1. 47.

Allen in Hollien 1973 - Allen, Elizabeth L., in Hollien, H., 1973. A laminagraphic study of pulse (vocal fry) register phonation. Folia phoniatrica XXV. 241-250.

Andruski in Costello 2004 - Andruski, Jean E., in Costello, James, 2004. Using polynomial equations to model pitch contour shape in lexical tones: An example from Green Mong. Journal of the International phonetic association XXXIV/2. $125-140$.

Aoki 1970 - Aoki, H., 1970. A note on glottalized consonants. Phonetica XXI/2. 6574.

Banguerel in Bhatia 1980 - Banguerel, André-Pierre, in Bhatia, Tej K., 1980. Hindi stop consonants: an acoustic and fiberscopic study. Phonetica XXXVII/3. 134148.

Belotel-Grenié in Grenié, 2004 - Belotel-Grenié, Agnès, in Grenié, Michel, 2004. The creaky voice phonation and the organisation of Chinese discourse. International Symposium on tonal aspects of languages: Emphasis on tone languages. Beijing, 28-30 March 2004. Http://www.lpl.univ-aix.fr/ sprosig/tal2004/tal2004Beijing/Belotel.pdf.

Berry 2001 - Berry, David A., 2001. Mechanisms of modal and nonmodal phonation. Journal of phonetics XXIX/4. 431-450.

Bezlaj 1960 - Bezlaj, France, 1960. Osnovne fonetike. Ljubljana.

Blomgren idr. 1998 - Blomgren, Michael, Chen, Yang, Ng, L. Manwa, in Gilbert, Harvey R., 1998. Acoustic, aerodynamic, physiologic, and peceptual properties of modal and vocal fry registers. Journal of the Acoustical society of America CIII/5. 2649-2658.

Catford 1964 - Catford, J. C., 1964. Phonation types. In honour of Daniel Jones. London: Longmans, Green. 26-37. 
Catford 1977 - Catford, J. C., 1977. Fundamental problems in phonetics. Edinburgh: Edinburgh university press.

Catford 1983 - Catford, J. C., 1983. Pharyngeal and laryngeal sounds in Caucasian languages. Vocal fold physiology: Contemporary research and clinical issues. San Diego: College Hill press. 344-350.

Coleman 1963 - Coleman, R. F., 1963. Decay characteristics of vocal fry. Folia phoniatrica XV. 256-263.

Dilley idr. 1996 - Dilley, L., Shattuck Hufnagel, S., in Ostendorf, M., 1996. Glottalization of word-initial vowels as function of prosodic structure. Journal of phonetics XXIV/4. 423-444.

Dixit 1989 - Dixit, R. Prakash, 1989. Glottal gestures in Hindi plosives. Journal of phonetics XVII/2. 213-237.

Ethnologue 2005 - Ethnologue: Languages of the world. Http://www.ethnologue.com. 4. 1.2005 .

Fant 1960 - Fant, Gunnar, 1960. Acoustic theory of speech production [...]. The Hague: Mouton (Description and analysis of contemporary Standard Russian, II).

Fant 1986 - Fant, Gunnar, 1986. Glottal flow: models and ineraction. Journal of phonetics XIV/3. 393-399.

Fischer-Jørgensen 1989 - Fischer-Jørgensen, Eli, 1989. Phonetic analysis of the stød in Standard Danish. Phonetica XLVI/1-3. 1-59.

Gerratt in Kreiman 2001 - Gerratt, Bruce R., in Kreiman, Jody, 2001. Toward a taxonomy of nonmodal phonation. Journal of phonetics XXIX/4. 365-381.

Gordon in Ladefoged 2001 - Gordon, Matthew, in Ladefoged, Peter, 2001. Phonation types: a cross-linguistic overview. Journal of phonetics XXIX/4. 383-406.

Greenberg 2004 - Greenberg, Marc L., 2004. Tonogenesis in Balto-Slavic. Tone and intonation in Europe. 2004 workshop: Typology of tone and intonation. 1-3 April 2004, Cascais. 11 str.

Grønnum in Basbøll 2001 - Grønnum, Nina, in Basbøll, Hans, 2001. Consonant length and morae in Standard Danish. Phonetica LVIII/4. 230-253.

Hanson 1997 - Hanson, Helen M., 1997. Glottal characteristics of female speakers: Acoustic correlates. Journal of the Acoustical society of America CI/1. 466-481.

Hanson idr. 2001 - Hanson, Helen M., Stevens, Kenneth N., Kuo, Hong-Kwang Jeff, Chen, Marilyn Y., in Slifka, Janet, 2001. Towards models of phonation. Journal of phonetics XXIX/4. 451-480.

Hanson in Chuang 1999 - Hanson, Helen M., in Chuang, Erika S., 1999. Glottal characteristics of male speakers: Acoustic corelates and comparison with female data. Journal of the Acoustical society of America CVI/2. 1064-1077.

Hayward 2000 - Hayward, Katrina, 2000. Experimental phonetics. Harlow: Longman (Longman linguistics library).

Hollien 1974 - Hollien, Harry, 1974. On vocal registers. Journal of phonetics II/1. $125-143$. 
Hollien idr. 1966 - Hollien, Harry, Moore, Paul, Wendahl, Ronald W., in Michel, John F., 1966. On the nature of vocal fry. Journal of speech and hearing research IX. 245-247.

Hollien idr. 1977 - Hollien, Harry, Girard, Gary T., in Coleman, Robert F., 1977. Vocal fold vibratory patterns of pulse register phonation. Folia phoniatrica XXIX. 200-205.

Hollien in Michel 1968 - Hollien, Harry, in Michel, John F., 1968. Vocal fry as a phonational register. Journal of speech and hearing research XI. 600-604.

Hollien in Wendahl 1968 - Hollien, Harry, in Wendahl, Ronald W., 1968. Perceptual study of vocal fry. Journal of the Acoustical society of America XLIII/3. 506-509.

Holmberg idr. 1988 - Holmberg, Eva B., Hillman, Robert E., in Perkell, Joseph S., 1988. Glottal airflow and transglottal air pressure measurements for male and female speakers in soft, normal, and loud voice. Journal of the Acoustical society of America LXXXIV/1. 511-529.

Holmberg idr. 1993 - Holmberg, Eva B., Perkell, Joseph S., Hillman, Robert E., in Gress, Carla, 1993. Individual variation in measures of voice. Phonetica CI/1-3. 30-37.

Hombert idr. 1979 - Hombert, Jean-Marie, Ohala, John J., in Ewan, William G., 1979. Phonetic explanations for the development of tones. Language LV/1. 37-58.

Houde in Hillenbrand 1994 - Houde, R. A., in Hillenbrand, J. M., 1994. The role of voice pitch in the perception of glottal stops. Journal of the Acoustical society of America XLV/S1. 2872.

Huffman 1987 - Huffman, Marie K., 1987. Measures of phonation type in Hmong. Journal of The acoustical society of America LXXXI/2. 495-504.

Johnson 1997 - Johnson, Keith, 1997. Acoustic and auditory phonetics. Malden: Blackwell publishers.

Jurgec 2004a - Jurgec, Peter, 2004. Antihiatski pojavi v knjižni slovenščini. Jezikoslovni zapiski X/1. 125-144.

Jurgec 2004b - Jurgec, Peter, 2004. Samoglasniški formanti standardne slovenščine: Končno poročilo o rezultatih raziskav. Neizdano gradivo. Ljubljana.

Jurgec 2005a - Jurgec, Peter, 2005a. Fonetični opis govora Ovčje vasi. V objavi.

Jurgec 2005b - Jurgec, Peter, 2005b. Samoglasniški nizi v slovenščini: Fonološkofonetična analiza. Ljubljana: Rokus in Slavistično društvo Slovenije (Slavistična knjižnica, 8), 2003. V tisku.

Klatt in Klatt 1990 - Klatt, Dennis H., in Klaat, Laura C., 1990. Analysis, synthesis, and perception of voice quality variations among female and male talkers. Journal of the Acoustical society of America LXXXVII/2. 820-857.

Kohler 1994 - Kohler, Klaus J., 1994. Glottal stops and glottalization in German. Phonetica $\mathrm{LI} / 1-3$. 38-51.

Kreiman idr. 1993 - Kreiman, Jody K., Gerratt, Bruce R., Kempster, Gail B., Erman, Andrew, in Berke, Gerald S., 1993. Perceptual evaluation of voice quality: Review, tutorial and framework for future research. Journal of speech and hearing research XXXVI. 21-40. 
Ladefoged 1971 - Ladefoged, Peter, 1971. Preliminaries to linguistic phonetics. Chicago idr.: The university of Chicago press.

Ladefoged 1973 - Ladefoged, Peter, 1973. The features of the larynx. Journal of phonetics I/1. 73-83.

Ladefoged 1983 - Ladefoged, Peter, 1983. The linguistic use of different phonation types. Vocal fold physiology: Contemporary research and clinical issues. San Diego: College Hill press. 351-360.

Ladefoged 1988 - Ladefoged, Peter, 1988. Discussion of phonetics: A note on some terms for phonation types. Vocal physiology: Voice production, mechanisms and functions. New York: Raven press (Vocal fold physiology, 2). 373-375.

Ladefoged 1993 - Ladefoged, Peter, 1993. A course in phonetics. Forth Worth idr.: Harcourt Brace college publishers.

Ladefoged 2003 - Ladefoged, Peter, 2003. Phonetic data analysis: An introduction to fieldwork and instrumental techniques. Malden idr.: Blackwell publishing.

Ladefoged idr. 1988 - Ladefoged, Peter, Maddieson, Ian, in Jackson, Michel, 1988. Investigating phonation types in different languages. Vocal physiology: Voice production, mechanisms and functions. New York: Raven press (Vocal fold physiology, 2). 297-317.

Ladefoged in Maddieson 1996 - Ladefoged, Peter, in Maddieson, Ian, 1996. The sounds of the world's languages. Malden idr.: Blackwell publishers.

Laver 1980 - Laver, John, 1980. The phonetic desctiption of voice quality. Cambridge idr.: Cambridge university press (Cambridge studies in linguistics).

Laver 1994 - Laver, John, 1994. Principles of phonetics. Cambridge idr.: Cambridge university press (Cambridge textbooks in linguistics).

Lehiste 1965 - Lehiste, Ilse, 1965. Juncture. Proceedings of the 5th international congress of phonetic sciences. Basel: S. Karger. 172-200.

Lehiste 1970 - Lehiste, Ilse, 1970. Suprasegmentals. Camridge idr.: The M. I. T. press.

Liénard 1999 - Liénard, Jean-Sylvain, 1999. Effect of vocal effort on spectral properties of vowels. Journal of the Acoustical society of America CVI/1. 411-422.

Lucero 1995 - Lucero, Jorge C., 1995. The minimum lung pressure to sustain vocal fold oscillation. Journal of the Acoustical society of America XCVIII/2. 779-784.

McGlone in Shipp 1971 - McGlone, Robert E., in Shipp, Thomas, 1971. Some physiologic correlates of vocal-fry phonation. Journal of speech and hearing research XIV. 769-775.

Michel in Hollien 1968 - Michel, John. F., in Hollien, Harry, 1968. Perceptual differentiation of vocal fry and harshness. Journal of speech and hearing research XI. 439-443.

Moore in von Leden 1958 - Moore, Paul, in von Leden, Hans, 1958. Dynamic Variations of the Vibratory Pattern in the Normal Larynx. Folia phoniatrica X. 205238.

Monsen idr. 1978 - Monsen, Randall B., Engebretson, A. Maynard, in Vemula, Rao N., 1978. Indirect assessment of the contribution of subglotal air pressure and vo- 
cal-fold tension to changes of fundamental frequency in English. Journal of the Acoustical society of America LXIV/1. 65-80.

Murry 1971 - Murry, Thomas, 1971. Subglottal pressure and airflow measures during vocal fry phonation. Journal of speech and hearing research XIV. 544-551.

Neweklowsky 1970 - Neweklowsky, Gerhard, 1970. Der laryngale Verschlußlaut im Slovenischen. Wiener Slavistisches Jahrbuch XVI. 104-111.

Neweklowsky 1973 - Neweklowsky, Gerhard, 1973. Slowenische Akzentstudien: Akustistische und linguistiche Untersuchungen am Material Slowenischer Mundarten aus Kärnten mit 46 Abbildungen und 76 Figuren in Text. Wien: Verlag der Österreichischen Akademie der Wissenschaften.

Ní Chasaide in Gobl 1997 - Ní Chasaide, Ailbhe, in Gobl, Christer, 1997. Voice source variation. The handbook of phonetic sciences. Oxford idr.: Blackwell publishers. $427-461$.

Ogden 2001 - Ogden, Richard, 2001. Turn-holding, turn-yielding and laryngeal activity in Finnish talk-in-interaction. Journal of the Internatonal phonetic association XXXI/2. 139-152.

Omerza 1970 - Omerza, Zdravko, 1970. Uporabna fonetika. Ljubljana: DZS.

Patterson in Connine 2001 - Patterson, David, in Connine, Cynthia M., 2001. Variant frequency in flap production. Phonetica LVIII/4. 254-275.

Pierrehumbert 1995 - Pierrehumbert, Janet, 1995. Prosodic effects on glottal allophones. Vocal fold physiology: Voice quality control. San Diego: Singular publishing group. 39-60.

Price idr. 1991 - Price, P. J., Ostendorf, M., Shattuck-Hufnagel, S., in Fong, C., 1991. The use of prosody in syntactic disambiguation. Journal of the Acoustical society of America XC/6. 2956-2970.

Priestly 1976 - Priestly, Tom M. S., 1976. A note on the glottal stop. Phonetica XXXIII/4. 268-274.

Priestly 1980 - Priestly, Tom, $1980 .{ }^{*} \mathrm{k}+$ dative in a Carinthian Slovene dialect. Folia Slavica IV/1. 25-34.

Purcell idr. 1978 - Purcell, E. T., Villegas, G., in Young, S. P., 1978. A before and after for tonogenesis. Phonetica XXXV/5. 284-293.

Redi in Shattuck-Hufnagel 2001 - Redi, Laura, in Shattuck-Hufnagel, S., 2001. Variation in the realization of glottalization in normal speakers. Journal of phonetics XXIX/4. 407-429.

Singh in Murry 1978 - Singh, Sadanand, in Murry, Thomas, 1978. Multidimensional classification of normal voice qualities. Journal of the Acoustical society of America LXIV/1. 81-87.

Smith idr. 1992 - Smith, Marshall E., Berke, Gerard S., Gerratt, Bruce R., in Kreiman, Jody, 1992. Laryngeal paralyses: Theoretical considerations and effects on laryngeal vibration. Journal of speech and hearing research XXXV. 545-554.

Srebot Rejec 1988 - Srebot Rejec, Tatjana, 1988. Word accent and vowel duration in Standard Slovene: An acoustic and linguistic investigation. München: Otto Sagner (Slavistische Beiträge, 226). 
Srebot Rejec 2000 - Srebot Rejec, Tatjana, 2000. Ali je današnja knjižna slovenščina še tonematična? Razprave II. razreda XVII. 51-66.

Stevens 1977 - Stevens, Kenneth N., 1977. Physics of laringeal behaviour and larynx modes. Phonetica XXXVI/4. 264-279.

Stevens 1998 - Stevens, Kenneth N., 1998. Acoustic phonetics. Cambridge, MA, London: The MIT press (Current studies in linguistics, 30).

Streeter 1978 - Streeter, Lyn, 1978. Acoustic determinants of phrase boundry perception. Journal of the Acoustical society of America LXIV/6. 1582-1592.

Švec idr. 1996 - Švec, Jan G., Schutte, Harm K., in Miller, Donald G., 1996. A subharmonic vibratory pattern in normal vocal folds. Journal of speech and hearing research XXXIX. 135-143.

Švec idr. 2000 - Švec, Jan G., Horáček, Jaromír, Šram, František, in Veselý, Jan, 2000. Resonance properties of the vocal folds: In vivo laryngoscopic investigation of the externally excited laryngeal vibrations. Journal of the Acoustical society of America CVIII/4. 1397-1407.

Titze 1988 - Titze, Ingo R., 1988. The physics of small-amplitude oscillation of the vocal folds. Journal of the Acoustical society of America LXXXIII/4. 1536-1552.

Titze 1992 - Titze, Ingo R., 1992. Phonation threshold pressure: A missing link in glottal aerodynamics. Journal of the Acoustical society of America XCI/5. 29262935.

Titze in Talkin 1979 - Titze, Ingo R., in Talkin, David T., 1979. A theoretical study of the effects of various laryngeal configurations on the acoustics of phonation. Journal of the Acoustical society of America LXVI/1. 60-74.

Thongkum 1988 - Thongkum, Theraphan L., 1988. Phonation types in Mon-Khmer languages. Vocal physiology: Voice production, mechanisms and functions. New York: Raven press (Vocal fold physiology, 2). 319-333.

Toporišič 1967 - Toporišič, Jože, 1967. Pojmovanje tonemičnosti slovenskega jezika. Slavistična revija $\mathrm{XV} / 1-2.64-108$.

Toporišič 1968 - Toporišič, Jože, 1968. Liki slovenskih tonemov. Slavistična revija $\mathrm{XVI} / 1-2.315-93$.

Toporišič 1989 - Toporišič, Jože, 1989. Slovenska knjižna tonemskost govora Jakoba Riglerja. Slavistična revija XXXVII/1-4. 61-96.

Trask 1996 - Trask, R. L., 1996. A dictionary of phonetics and phonology. London idr.: Routledge.

Traill in Jackson 1988 - Traill, Anthony, in Jackson, Michel, 1988. Speaker variation and phonation type in Tsonga nasals. Journal of phonetics XVI/3. 385-400.

Umeda 1978 - Umeda, Noriko, 1978. Occurrence of glottal stops in fluent speech. Journal of the Acoustical society of America LXIV/1. 88-94.

Vodušek 1961 - Vodušek, Božo, 1961. Grudsätzliche Betrachtungen über den melodischen Verlauf der Wortakzente in den zentralen Slowenichen Mundarten. Linguistica IV. 20-38. 
Wendahl idr. 1963 - Wendahl, R. W., Moore, G. P., in Hollien, H., 1963. Comments on vocal fry. Folia phoniatrica XV. 251-255.

Whitehead idr. 1984 - Whitehead, Robert L., Metz, Dale E., in Whitehead Brenda H., 1984. Vibratory patterns of vocal folds during pulse register phonation. Journal of the Acoustical society of America LXXV/4. 1293-1297.

Žganec Gros idr. 2003 - Žganec Gros, Jerneja, Mihelič, France, in Dobrišek, Simon, 2003. Govorne tehnologije: pridobivanje in pregled govornih zbirk za slovenski jezik. Jezik in slovstvo XLVIII/3-4. 47-59.

Prispelo januarja 2005, sprejeto februarja 2005

Received January 2005, accepted February 2005

\section{Začetne opombe k laringalizaciji v slovenščini}

Članek predstavlja začetno fazo raziskave nemodalne fonacije v slovenščini s poudarkom na hripavemu glasu. Izhodišče je splošno fonetično; povzete so ugotovitve artikulacijske in akustične fonetike (Ladefoged, Laver, Catford idr.) v zvezi s fonacijskimi možnostmi v jezikih sveta, ki so navedeni povzemalno. Laringalizacija je razumljena ladefogedovsko, torej kot termin, ki je nekoliko širši od hripavega glasu.

Dosedanje raziskave slovenščine so obsegale zlasti status glotalnega zapornika in alofonske laringalizacije v rožanskem in podjunskem narečju (Neweklowsky, Priestly), pa tudi v standardni slovenščini (avtor). Postavljeno je tudi vprašanje o vlogi hripavega glasu v slovenski tonogenezi (Greenberg).

Eksperimentalni del je dvodelen in vključuje gradivo standardne slovenščine in narečno gradivo ziljskega govora v Kanalski dolini (Ovčja vas). Prvo gradivo sestavljajo studijski posnetki izoliranih besed, največji del so eno- do trizložnice, izbrane glede na nadsegmentne lastnosti (204 minute), skupno desetih govorcev. Narečno gradivo je vodeni intervju, upoštevan je predvsem govor ene govorke (29 minut). Laringalizacija je bila $\mathrm{v}$ obeh primerih določena slušno in preverjena akustično s programi za digitalno analizo govora, dvomljivi primeri so bili izločeni.

Gradivo standardne slovenščine je pokazalo precejšnjo individualno variabilnost pri laringalizaciji, kar se ujema $\mathrm{z}$ dosedanjimi ugotovitvami za druge jezike. Razlika $\mathrm{v}$ pogostnosti laringalizacije med moškimi in ženskami, tonemskimi in netonemskimi govorci ni statistično značilna. Laringalizacija se pojavlja v 585 analiziranih enotah oz. $11,6 \%$, in sicer v obliki hripavega glasu, hripa, diplofoničnih spremljevalnih elementov, subharmoničnega nihanja ipd. Tipološko je laringalizacija glede na mesto in način pojavljanja razdeljena $v$ tri tipe, kar je pogojeno s sestavo gradiva. Laringalizacija tipa 1 se pojavlja $\mathrm{v}$ vzglasju, lahko pa tudi na morfemski meji, posebej $\mathrm{v}$ tipu $\mathrm{V}]_{\mathrm{m}}[\mathrm{V}$. Značilna je variantnost $\mathrm{z}$ glotalnim zapornikom, ki je $\mathrm{v}$ gradivu kar pogost $(30,2 \%$ enot $\mathrm{s}$ samoglasniškim vzglasjem). Pojavlja se tudi na morfemski meji namesto $/ \mathrm{j} /$, npr. /kup't'ìja/. Laringalizacija tipa 2 je nevzglasna, največkrat pa izglasna. Segmenti (samoglasniki, redkeje zvočniki) so laringalizirani v celoti ali v pretežnem delu. Skupno je bilo laringaliziranih vsaj 385 segmentov v dvo- in trizložnicah gradiva. Naglašeni segmenti so redkeje laringalizirani, ponaglasni in poponaglasni predstavljajo veliko večino pojavitev. Čim daljša je beseda, večja je verjetnost laringalizacije katerega od njenih 
(ponaglasnih) segmentov. Laringalizacija je v tonemski slovenščini statistično značilno redkejša $\mathrm{v}$ ponaglasnem zlogu besed $\mathrm{z}$ akutom $\mathrm{v}$ primerjavi s cirkumflektiranimi, zlasti pri paroksitonih. Te razlike pri netonemskih govorcih ni. To je povezano $\mathrm{z}$ dejstvom, da je laringalizacija verjetnejša, ko je ton nizek in če je segment manjše intenzitete, za slovenske akute pa v ponaglasnem zlogu velja ravno nasprotno. Laringalizacija tipa 3 je prisotna $\mathrm{v}$ celotnem poteku intonacijske enote (npr. pardon, ok, v redu, ja). Ta se pojavlja parajezikovno.

V narečnem gradivu se ravno tako pojavljajo omenjeni trije tipi laringalizacije; skupni delež laringaliziranih enot je primerljiv s stanjem za standardni jezik, tj. 11,4 \%. Laringalizacija tipa 2 se pogostneje povezuje $\mathrm{z}$ akutiranimi paroksitoni, kar je drugače kot v standardni slovenščini; ta tip akuta je padajoč, saj je stavčnointonacijsko pogojen (druga možnost končne intonacije $v$ tem gradivu je falzetna fonacija).

$\mathrm{V}$ zadnjem delu so prikazani trije tipi povezani s splošnejšimi ugotovitvami za druge jezike, kjer so upoštevani tako fonološki segmentni (npr. kontrasti med hripavimi in modalnimi samoglasniki v nekaterih jezikih, prim. še stanje $v$ delu rožanskega in podjunskega narečja ali v pogovorni ljubljanščini) in nadsegmenti (povezanost hripavega glasu z določenim tonom, najraje nizkim; v slovenščini to velja za ponaglasni zlog cirkumfleksa), fonetični prozodični (alofonsko zaznamovanje meje in nadsegmentnih lastnosti), pragmatični (npr. ob koncu izreka; v slovenščini izraža tudi nedokončanost $\mathrm{v}$ povezavi $\mathrm{z}$ medmetno rabo), parajezikovni ( $\mathrm{v}$ angleščini npr. izraža zdolgočasenost, v slovenščini tudi oklevanje, negotovost), sociolingvistični (hripavi glas se v nekaterih jezikih povezuje z višjim socialnim statusom; odvisnost od spola) in zunajjezikovni (individualne razlike $v$ realizaciji).

V nadaljevanju so potrebne podrobnejše študije vpliva prozodičnih spremenljivk na laringalizacijo $\mathrm{v}$ slovenščini (standardni in narečni) na podlagi analize označenih računalniško berljivih zbirk govora, kakor tudi morebitna povezanost $\mathrm{s}$ fonološkimi spremenljivkami, še posebej naglasom in tonsko višino. Zanimive bi bile tudi nadaljnje jazikoslovno relevantne akustične študije glasu.

\section{Preliminary remarks on laryngealization in Slovene}

The article presents the initial phase of research on non-modal phonation in Slovene with an emphasis on creaky voice. The approach comes from general phonetics; an overview of the discoveries from articulatory and acoustic phonetics (Ladefoged, Laver, Catford, etc.) are given in connection with the phonation possibilities in world languages, which are listed in summary fashion. Laryngealization is understood in Ladefoged's sense, that is, as a term referring to a broader phenomenon than creaky voice.

Studies to date on Slovene have mainly covered the status of the glottal stop and allophonic laryngealization in Rož in the Podjuna subdialect of Carinthian (Neweklowsky, Priestly), as well as in Standard Slovene (Jurgec). The question has also been posed whether there is a connection between creaky voice and Slovene tonogenesis (Greenberg). 
The experimental part is divided into two sections and includes material from Standard Slovene and dialect material from the locality Ovčja vas in the Kanal Valley, which belongs to the Zilja subdialect of Carinthian. The first set of material is comprised of studio recordings of isolated words, largely mono-, di- and trisyllables, selected with regard to their suprasegmental properties (204 minutes), from ten speakers. The dialect material is from a guided interview in which the speech of one female informant is considered (29 minutes). Laryngealization was in both cases determined by ear and verified acoustically with programs for digital speech analysis; doubtful examples were removed from consideration.

The Standard Slovene material indicated a high degree of individual variability in laryngealization, which agrees with what has been discovered so far for other languages. The difference in the frequency of laryngealization between men and women as well as tonemic and non-tonemic speakers is not statistically relevant. Laryngealization occurs in 585 analyzed samples or $11.6 \%$ and is manifested as creaky voice, creak, diplophonic, subharmonic and similar phenomena. Typologically, laryngealization is divided into three types with respect to place and manner of articulation, which is conditioned by the composition of the material. Type 1 laryngealization occurs in onset position as well as on a morpheme boundary, particularly in the type $\mathrm{V}]_{\mathrm{m}}[\mathrm{V}$. Characteristically, this type is in free variation with glottal stop, which is attested quite frequently in the material (30.2\% of the examples with vocalic onset). It also occurs on a morpheme boundary in place of /j/, e.g., /kup'tiija/ 'purchase'. Type 2 laryngealization is non-word-initial, usually word-final. Segments (vowels, more rarely, sonorants) are laryngealized either completely or nearly so. Altogether there were 385 laryngealized segments in the di- and trisyallibic material. Stressed segments were laryngealized less frequently, while post-tonic syllables represented the majority of instantiations. The longer the word, the greater was the likelihood of laryngealization of one of the (posttonic) segments. Laryngealization in tonemic Slovene is statistically significantly rarer in post-tonic syllables of acute-stressed words in comparison with circumflex-stressed words, especially paroxytones. These differences did not occur with non-tonemic speakers. This is connected with the fact that laryngealization is more likely to occur with low tone and lower-intensity segments; this is precisely the opposite situation with the Slovene acute-stressed words in post-tonic syllables. Type 3 laryngealization is present throughout the entire intonational unit (e.g., pardon, ok, v redu, ja). This is a paralinguistic phenomenon.

The same three types of laryngealization occur in the dialect material; the total share of laryngealized examples is comparable to that found in Standard Slovene, i.e., $11.4 \%$. Type 2 laryngealization occurs more often in connection with acute-stressed paroxytones, which is different than in Standard Slovene. This type of acute is falling, being that it is conditioned by sentence intonation (another manifestation of final intonation in this corpus is falsetto phonation).

The last section presents the three types in conjunction with the results of research on other languages and considereds: phonological segments (e.g., contrasts between creaky voice and modal vowels in certain languages, cf. the situation in part of the Rož and Podjuna subdialects and in the Ljubljana vernacular), suprasegmentals (the connection between creaky voice and a specific tone, usually low tone; in Slovene this is true in particular of the post-tonic syllable in circumflex-stressed words), phonetic prosody 
(allophonic marking of a boundary and suprasegmental properties), pragmatics (e.g., utterance-final; in Slovene expressing, among other things, incompleteness in connection with interjection), paralinguistic phenomena (e.g., in English expressing boredom, in Slovene indecisiveness, uncertainty), sociolinguistic phenomena (in some languages creaky voice marks higher social status; gender dependency), and extralinguistic phenomena (individual differences in realization).

Future research calls for a more detailed study of the influence of prosodic variables on laryngealization in Slovene (standard and dialectal) on the basis of analysis of computer-readable speech corpora, including, perhaps, the connection between phonological variables, especially stress and pitch. Linguistically significant voice studies are needed as well. 